\title{
Emissions of biogenic volatile organic compounds and subsequent photochemical production of secondary organic aerosol in mesocosm studies of temperate and tropical plant species
}

\author{
K. P. Wyche ${ }^{1,2}$, A. C. Ryan $^{3}$, C. N. Hewitt ${ }^{3}$, M. R. Alfarra ${ }^{4,5}$, G. McFiggans ${ }^{4}$, T. Carr ${ }^{1}$, P. S. Monks ${ }^{1}$, K. L. Smallbone ${ }^{2}$, \\ G. Capes $^{5}$, J. F. Hamilton ${ }^{6}$, T. A. M. Pugh ${ }^{7}$, and A. R. MacKenzie ${ }^{8}$ \\ ${ }^{1}$ Department of Chemistry, University of Leicester, Leicester, LE1 7RH, UK \\ ${ }^{2}$ Air Environment Research Group, School of Environment and Technology, University of Brighton, Brighton, BN2 4GJ, UK \\ ${ }^{3}$ Lancaster Environment Centre, Lancaster University, Lancaster, LA1 4YQ, UK \\ ${ }^{4}$ Centre for Atmospheric Science, School of Earth, Atmospheric and Environmental Sciences, University of Manchester, M13 \\ 9PL, UK \\ ${ }^{5}$ National Centre for Atmospheric Science, University of Manchester, M13 9PL, UK \\ ${ }^{6}$ Wolfson Atmospheric Chemistry Laboratories, Department of Chemistry, University of York, York, YO10 5DD, UK \\ ${ }^{7}$ Karlsruhe Institute of Technology, IMK-IFU, Garmisch-Partenkirchen, Germany \\ ${ }^{8}$ Birmingham Institute of Forest Research, University of Birmingham, B15 2TT, UK
}

Correspondence to: A. C. Ryan (a.ryan@lancaster.ac.uk)

Received: 4 April 2014 - Published in Atmos. Chem. Phys. Discuss.: 2 June 2014

Revised: 16 September 2014 - Accepted: 18 October 2014 - Published: 5 December 2014

\begin{abstract}
Silver birch (Betula pendula) and three Southeast Asian tropical plant species (Ficus cyathistipula, Ficus benjamina and Caryota millis) from the pantropical fig and palm genera were grown in a purpose-built and environmentcontrolled whole-tree chamber. The volatile organic compounds emitted from these trees were characterised and fed into a linked photochemical reaction chamber where they underwent photo-oxidation under a range of controlled conditions (relative humidity or RH $\sim 65-89 \%$, volatile organic compound-to- $\mathrm{NO}_{\mathrm{x}}$ or $\mathrm{VOC} / \mathrm{NO}_{\mathrm{x}} \sim 3-9$ and $\mathrm{NO}_{\mathrm{x}} \sim 2 \mathrm{ppbV}$ ). Both the gas phase and the aerosol phase of the reaction chamber were monitored in detail using a comprehensive suite of on-line and off-line chemical and physical measurement techniques.

Silver birch was found to be a high monoterpene and sesquiterpene but low isoprene emitter, and its emissions were observed to produce measurable amounts of secondary organic aerosol (SOA) via both nucleation and condensation onto pre-existing seed aerosol ( $\left.Y_{\mathrm{SOA}} 26-39 \%\right)$. In contrast, all three tropical species were found to be high isoprene emitters with trace emissions of monoterpenes and sesquiterpenes. In tropical plant experiments without seed aerosol
\end{abstract}

there was no measurable SOA nucleation, but aerosol mass was shown to increase when seed aerosol was present. Although principally isoprene emitting, the aerosol mass produced from tropical fig was mostly consistent (i.e. in 78 out of 120 aerosol mass calculations using plausible parameter sets of various precursor specific yields) with condensation of photo-oxidation products of the minor volatile organic compounds (VOCs) co-emitted; no significant aerosol yield from condensation of isoprene oxidation products was required in the interpretations of the experimental results. This finding is in line with previous reports of organic aerosol loadings consistent with production from minor biogenic VOCs co-emitted with isoprene in principally isopreneemitting landscapes in Southeast Asia. Moreover, in general the amount of aerosol mass produced from the emissions of the principally isoprene-emitting plants was less than would be expected from published single-VOC experiments, if coemitted species were solely responsible for the final SOA mass. Interpretation of the results obtained from the fig data sets leaves room for a potential role for isoprene in inhibiting SOA formation under certain ambient atmospheric con- 
ditions, although instrumental and experimental constraints impose a level of caution in the interpretation of the results.

Concomitant gas- and aerosol-phase composition measurements also provide a detailed overview of numerous key oxidation mechanisms at work within the systems studied, and their combined analysis provides insight into the nature of the SOA formed.

\section{Introduction}

Atmospheric aerosols change the radiative balance of the Earth through scattering and absorbing incident solar radiation (Kim and Ramanathan, 2008); they directly and indirectly affect the properties and formation of clouds, thus altering the hydrological cycle (Gunthe et al., 2009; Junkermann et al., 2009; Stevens and Feingold, 2009); and they may have an impact on the efficiency of plant photosynthesis (Mercado et al., 2009), thereby modifying the uptake of atmospheric carbon. Hence, aerosol particles affect the Earth's climate in several ways (as reviewed in Hallquist et al., 2009; IPCC, 2007; Isaksen et al., 2009; Carslaw et al., 2010) as well as having a detrimental impact on human health (e.g. Baltensperger et al., 2008).

A large fraction of the observed atmospheric aerosol composition is organic (Zhang et al., 2007). A primary organic component is emitted directly into the atmosphere from anthropogenic activities, such as biomass burning and fossil fuel combustion, or is emitted from natural sources, such as plant abrasion and the sea surface. Secondary aerosol particles are formed within the atmosphere by gas-to-particle conversion; those formed from gas-phase organic precursors are known as secondary organic aerosol (SOA; e.g. Riipinen et al., 2012). There is considerable uncertainty surrounding the chemical transformation of anthropogenic and biogenic volatile organic compounds (AVOCs and BVOCs, respectively) from the gas phase to the aerosol phase and hence, considerable uncertainty about the global source of SOA (Hallquist et al., 2009; Donahue et al., 2009; $\mathrm{Ng}$ et al., 2006; Virtanen et al., 2010).

On a global scale, approximately $90 \%$ of all volatile organic compound (VOC) emissions originate from biogenic sources (Guenther et al., 2012), with almost half of this being emitted from tropical and subtropical forests. The ability of BVOCs to form SOA is therefore of particular interest and potential importance. Globally, isoprene (2-methyl-1,3butadiene, $\mathrm{C}_{5} \mathrm{H}_{8}$ ) is the BVOC with the largest mass emission rate. It is estimated to account for about $50 \%$ of BVOC emissions by mass (Guenther et al., 2012), but it is still uncertain how much it contributes to SOA formation (Karl et al., 2009; Carlton et al., 2009).

Modelling, laboratory chamber experiments and field studies provide a range of possible yields of SOA from isoprene, typically of the order of $0.1-3 \%$ by mass, with some values reported as high as $5.5 \%$ (van Donkelaar et al., 2007; Kleindienst et al., 2007, 2009; Kroll et al., 2005, 2006; Claeys et al., 2004a; Edney et al., 2005; Brégonzio-Rozier et al., 2014). SOA yields from the further oxidation of firstand subsequent-generation isoprene oxidation products, such as methacrolein, are estimated to be as much as $15 \%$ (Rollins et al., 2009; Carlton et al., 2009; Claeys et al., 2004b; Robinson et al., 2009). Recent work has highlighted that under low $\mathrm{NO}_{\mathrm{x}}$ conditions, SOA mass formed from isoprene oxidation could be influenced by the acidity of pre-existing aerosol via the reactive uptake of certain key isoprene oxidation products, namely isoprene epoxydiols (IEPOX; Surratt et al., 2010; P. Lin et al., 2012). More recently, Nguyen et al. (2014) found that the " $\mathrm{pH}$ dependence for OA [organic aerosol] formation from IEPOX was weak for AS [ammonium sulfate] particles". There is further evidence from chamber studies using temperate tree species such as birch, spruce and pine that isoprene may in fact suppress SOA formation from other VOC precursors, when present (KiendlerScharr et al., 2009a; Kanawade et al., 2011). It should be noted at this point that it is unclear in most cases how wall effects have been considered in the production of such SOA yield values and whether the treatments employed are adequate to ensure that the yields are comparable between chambers, or indeed between experiments.

Here, we characterised the BVOC emissions from three Southeast Asian tropical plant species (Ficus cyathistipula, Ficus benjamina and Caryota millis) and, in a series of coupled plant growth chamber-atmospheric reaction chamber experiments, examined the ability of their oxidation products to contribute to SOA formation under atmospherically relevant conditions. In order to provide a geographically and chemically contrasting study, we replicated these experiments using common silver birch (Betula pendula). Silver birch has previously been shown to contribute to the formation of SOA via the emissions of mono- and sesquiterpenes (e.g. Kiendler-Scharr et al., 2009a, b; Mentel et al., 2009). Seeded (ammonium sulfate) and unseeded experiments were carried out to allow studies of both fresh nucleation and condensation onto pre-existing aerosol.

\section{Methods and materials}

\subsection{Plant selection and pre-screening}

Three nonclonal specimens of common silver birch $(B e$ tula pendula), a monoterpene- and isoprene-emitting tree species; two species of fig (Ficus benjamina and Ficus cyathistipula), and one species of palm (Caryota millis), each approximately $1.5 \mathrm{~m}$ in height were used. Figs and palms are abundant in all tropical rainforests. We chose three species found in abundance throughout South and Southeast Asia to be consistent with our field work (Hewitt et al., 2010; MacKenzie et al., 2011). Ficus benjamina (Moraceae) 
is native to Malaysia and has previously been found to be a high isoprene emitter $\left(0.03-8.7 \mu \mathrm{g} \mathrm{C} \mathrm{g}-1 \mathrm{~h}^{-1}\right.$, potted and in soil) with emissions of the monoterpenes limonene $\left(0.02 \mu \mathrm{g} \mathrm{g} \mathrm{g}^{-1} \mathrm{~h}^{-1}\right)$ and $\beta$-ocimene $\left(1.8-2.5 \mu \mathrm{g} \mathrm{Cg} \mathrm{g}^{-1} \mathrm{~h}^{-1}\right)$ and the sesquiterpenes $\beta$-caryophyllene and $\alpha$-copaene (Carvalho et al., 2005; Geron et al., 2006). In addition, emissions of benzaldehyde $\left(0.53 \mu \mathrm{g} \mathrm{Cg} \mathrm{g}^{-1} \mathrm{~h}^{-1}\right)$ and acetaldehyde $\left(69 \mu \mathrm{g} \mathrm{C}^{-1} \mathrm{~h}^{-1}\right)$ from potted specimens have been detected (Carvalho et al., 2005). No previous data are available on the BVOC emissions from Ficus cyathistipula or Caryota millis. Proton-transfer-reaction mass spectrometry (PTR-MS) and gas-chromatography mass spectrometry (GC-MS) screening, prior to the start of the coupled chamber experiments, confirmed that both species were high isoprene emitters, with Ficus cyathistipula also emitting limonene, $\beta$-phellandrene, $\alpha$-damascone and acetaldehyde. Analytical methods are described in detail in Sect. 2.4.

\subsection{Plant chamber design}

A $4.7 \mathrm{~m}^{3}$ plant chamber was constructed out of two rectangular Teflon bag sections and a $0.05 \mathrm{~mm}$ fluorinated ethylene propylene (FEP) Teflon lid (Adtech Polymer Engineering, UK), which were each supported by frames built using $25 \mathrm{~mm}^{2}$ box aluminium (Speed Frame, RS Components, UK). The framework stood on a raised foil- and Tefloncovered marine plywood base. PVC foam strips (RS Components, UK) ensured an airtight seal between chamber sections. Heavy-duty double-sided tape (RS components, UK) was used to secure the Teflon bags to the frame. The interior of the plant chamber was only exposed to Teflon surfaces.

Compressed air was constantly supplied to the plant chamber via a mass-flow controller and regulator (ALICAT MCR500 SLPM-D, Premier Control Technologies Ltd, UK) at $780 \mathrm{~L} \mathrm{~min}^{-1}$ and $7.5 \mathrm{bar}$ via a $12.7 \mathrm{~mm}$ outer diameter (OD) reinforced tube. This was reduced to $\sim 1$ bar and between 250 to $300 \mathrm{~L} \mathrm{~min}^{-1}( \pm 0.8 \%)$ dependent on the photosynthetic and transpiration rates of each plant species (equivalent to one complete air change every $15-20 \mathrm{~min}$ ). The airstream was passed through a $12.7 \mathrm{~mm}$ (OD) polytetrafluoroethylene (PTFE) tube to three in-series filters to remove any pre-existing VOCs (activated carbon filter P3KFA14ASMN, Parker Pneumatic, UK), and submicrometer particles (highefficiency particulate air or HEPA CAP 75 filter capsule; FDP-780-050K, Fisher Scientific, UK) and $\mathrm{NO}_{\mathrm{x}}$ (Purafil and activated charcoal, Purafil, Inc., USA). Finally, the air was rehumidified by passing it through a $2 \mathrm{~L}$ Teflon barrel (Jencons, UK) filled with warmed distilled water. The plant chamber outlet air was either vented into the laboratory via a $50 \mathrm{~mm}$ (OD) stainless steel pipe and valve, or used to fill an $18 \mathrm{~m}^{3}$ Teflon reaction chamber.

To enhance mixing, air entered the plant chamber via a perforated $12.7 \mathrm{~mm}$ (OD) PTFE tube that circled the base of the chamber. One $12.7 \mathrm{~mm}$ stainless steel bulkhead fitting (Swagelok, UK) was inserted through the frame to secure the
PTFE tube to the base of the plant chamber. A $50 \mathrm{~mm}$ (OD) stainless steel pipe was inserted into the upper corner of the chamber and supported by a Teflon (inner surface) and nylon (outer surface) manifold (Plastics Direct, UK). The manifold also supported an environmental gas monitor (EGM) probe (EGM-4, PP Systems, UK), which recorded relative humidity $(\mathrm{RH})$, temperature, $\mathrm{CO}_{2}$ and photosynthetically active radiation (PAR).

Plants were kept in 255-330 mm (height) pots depending on species, watered to pot dripping point and sprayed twice weekly. Plant chamber conditions were maintained at 31$33.5^{\circ} \mathrm{C} / 22-24{ }^{\circ} \mathrm{C}$ (day/night), 29-40\%/33-44\% (day/night) $\mathrm{RH}$ and 335-385 ppmV/390-404 ppmV (day/night) $\mathrm{CO}_{2}$. Owing to structural restrictions, PAR could not be measured directly under the growth lamps in the centre of the canopy. At the top edge of the canopy it was $500 \mu \mathrm{mol} \mathrm{m}^{-2} \mathrm{~s}^{-1}$ with a $12 \mathrm{~h}$ day/night cycle.

\subsection{Reaction chamber description}

The aerosol photochemical reaction chamber at the University of Manchester is composed of an $18 \mathrm{~m}^{3}$ FEP Teflon bag mounted on three rectangular extruded aluminium frames (Alfarra et al., 2012). A bank of halogen lamps and a $6 \mathrm{~kW}$ xenon arc lamp are mounted on the enclosure housing the bag, which is coated with reflective "space blanket" to provide an integrating sphere, maximising the irradiance in the bag and ensuring even illumination for the production of photochemical species such as the hydroxyl radical $(\mathrm{OH})$. The air introduced into the bag is dried and filtered for gaseous impurities and particles, prior to humidification with high-purity deionised water. A high-capacity $\mathrm{O}_{3}$ generator provides controlled ambient levels of $\mathrm{O}_{3}$ (used as an oxidant) and high $\mathrm{O}_{3}$ concentrations (serving as a cleaning agent between experiments).

Size-dependent (diffusional and gravitational) wall loss rate constants were calculated based on particle mobility and the surface-to-volume ratio of the chamber (Verheggen and Mozurkewich, 2006). The diffusional loss rate relies on a constant of proportionality, which can only be determined empirically. A time period was selected near the end of each experiment when the wall losses were deemed to be the dominant process affecting the size distribution. The volume size distribution at the beginning of this period had the calculated wall loss rate applied to simulate the evolution of the size distribution over the selected time period. If the calculated loss rate loss rate did not reproduce the measured volume evolution within the specified tolerance (1-2\% in this study), the constant of proportionality for diffusional losses was adjusted such that the simulated volume at the end of the selected period matched the measured volume within the specified tolerance. The time-integrated gravitational and (optimised) diffusional loss rate constants were then applied to the volume size distribution throughout the experiment in order to reconstruct a wall loss-corrected size distribution, which 
was then used to calculate the wall loss-corrected particle mass.

Both the plant chamber and reaction chamber were tested for contaminants separately and when joined together by running the system with an empty plant chamber and by carrying out a "blank" run prior to each set of experiments.

\subsection{Analytical techniques}

\subsubsection{Gas-phase measurements}

The volatile and semivolatile organic compounds (SVOC) and oxygenated volatile organic compounds (OVOC) in both the plant chamber and the reaction chamber were measured by soft-ionisation mass spectrometry (specifically, PTR-MS and CIR-ToF-MS, described below) and by GC-MS.

The PTR-MS instrument employed (Ionicon, Austria) comprises two turbomolecular pumps, a heated silica steel inlet system and a $9.6 \mathrm{~cm}$ long stainless steel drift tube. The nominal response time is approximately $1 \mathrm{~s}$. The operating parameters of the PTR-MS were held constant during measurements, except for the secondary electron multiplier voltage, which was optimised each day. The drift tube pressure, temperature and voltage were $2.2 \mathrm{hPa}, 50^{\circ} \mathrm{C}$ and $600 \mathrm{~V}$, respectively. The central reaction chamber of the drift cell was operated at an $E / N$ (i.e. electric field/gas number density) ratio of $125 \mathrm{Td}$. The count rate of hydrated hydronium $\left(\mathrm{H}_{3} \mathrm{O}^{+} \cdot \mathrm{H}_{2} \mathrm{O}\right)$ ions was $1-2 \%$ of the count rate of $\mathrm{H}_{3} \mathrm{O}^{+}$ions. The PTR-MS sampled continuously with a flow rate of 100$150 \mathrm{~mL} \mathrm{~min}^{-1}$ through $3.2 \mathrm{~mm}$ PTFE tubing.

The chemical-ionisation-reaction time-of-flight mass spectrometer (CIR-ToF-MS) comprises a temperaturecontrolled $\left(40( \pm 1){ }^{\circ} \mathrm{C}\right)$ ion-source drift cell assembly coupled to an orthogonal time-of-flight mass spectrometer equipped with a reflectron array (Kore Technology Ltd, Ely, UK). The ion source deployed was a hollow cathode discharge type (Blake et al., 2009) and the chemical ionisation technique used was proton transfer reaction from hydrated hyrdonium (Jenkin et al., 2012). Sample air was delivered in a continuous stream directly to the drift cell via a $0.5 \mathrm{~m}$ long, $6.35 \mathrm{~mm}$ internal diameter (ID) Teflon sample line, heated to $40( \pm 1)^{\circ} \mathrm{C}$, at a constant flow rate of $80 \mathrm{~mL} \mathrm{~min}^{-1}$. The central reaction chamber of the drift cell was operated at an $E / N$ ratio of $\sim 90-100 \mathrm{Td}$, with a tuned energy ramp at the base of the cell to remove potential water-cluster ions (e.g. $\mathrm{RH}^{+} \cdot \mathrm{H}_{2} \mathrm{O}$ ). Further information regarding the CIR-ToF-MS design and a detailed discussion regarding its operation can be found in Blake et al. (2003) and Wyche et al. (2007).

The PTR-MS and CIR-ToF-MS were calibrated using three different methods: (1) step-wise dilution of a gravimetrically prepared gas standard (BOC Special Gases, UK) containing a variety of VOCs and OVOCs; (2) using calibration material produced in house via the injection of liquid samples into $10 \mathrm{~L}$ Tedlar bags (SKC, Inc., USA) containing either humidified or dry, pure nitrogen; and (3) using gas standards derived from permeation tubes (Vici, Inc., USA; Ecoscientific, UK), diluted, humidified and delivered by a commercial calibration unit (KIN-TEK Laboratories, Inc., USA; model: 491). Where experimental calibration was not possible for a specific compound, either the calibration sensitivity for a structurally similar surrogate was used or calculated concentrations were employed (Jenkin et al., 2012). For the quantification of isobaric signals, a single sensitivity value was used, for example $\alpha$-pinene sensitivity for $\Sigma$ (monoterpenes) and $\beta$-caryophyllene sensitivity for $\Sigma$ (sesquiterpenes); again working on the principle that structurally similar compounds possess similar PTR and CIR sensitivities.

CIR-ToF-MS and PTR-MS detection limits are reagent, reaction-, analyte- and sample matrix-specific. However, typical CIR-ToF-MS detection limits, using PTR ionisation from hydronium, are of the order of $0.4 \mathrm{ppbV}(10 \mathrm{~min})^{-1}$ for more polar compounds, such as OVOCs (e.g. 2-hexanone) and as much as $10 \mathrm{ppbV} \mathrm{min}^{-1}$ for certain less polar compounds, such as smaller hydrocarbons (e.g. 1-pentene). For further details see Wyche et al. (2007).

The GC-MS system (GC-MS Turbomass Gold, PerkinElmer, USA) comprised a thermal desorption autosampler (PerkinElmer ATD 400) connected via a heated $\left(200^{\circ} \mathrm{C}\right)$ transfer line to a Hewlett-Packard 5890 GC with a 5970 mass-selective detector. Compounds were desorbed at $280{ }^{\circ} \mathrm{C}$ for $5 \mathrm{~min}$ at $25 \mathrm{~mL} \mathrm{~min}^{-1}$ onto a Tenax-TA cold trap maintained at $-30^{\circ} \mathrm{C}$. The cold trap was then heated to $300^{\circ} \mathrm{C}$ for $6 \mathrm{~min}$ to desorb compounds onto the $\mathrm{GC}$ column. Chromatographic separation was achieved using an Ultra-2 column (Agilent Technologies: $50 \mathrm{~m} \times 0.2 \mathrm{~mm}$ ID $\times 0.11 \mu \mathrm{m}$ film, $5 \%$ phenylmethyl silica). Oven temperature was initially set at $35^{\circ} \mathrm{C}$, maintained for $2 \mathrm{~min}$ and then increased at $4{ }^{\circ} \mathrm{C} \mathrm{min}^{-1}$ to $160{ }^{\circ} \mathrm{C}$, followed by an increase of $45^{\circ} \mathrm{C} \mathrm{min}{ }^{-1}$ to $300^{\circ} \mathrm{C}$, which was maintained for $10 \mathrm{~min}$. The carrier gas was helium supplied at a rate of $1 \mathrm{~mL} \mathrm{~min}^{-1}$, with an injector temperature of $250^{\circ} \mathrm{C}$. The limit of detection was approximately $0.25 \mathrm{ng}$ on column for isoprene and monoterpenes and $2 \mathrm{ng}$ on column for sesquiterpenes, corresponding to $100 \mathrm{pptV}$ of isoprene, $50 \mathrm{pptV}$ of monoterpenes and $400 \mathrm{pptV}$ of sesquiterpenes in a $1 \mathrm{~L}$ sample. Sampling was conducted by drawing $8 \mathrm{~L}$ of the analyte air through $6.35 \mathrm{~mm}$ PTFE tubing onto the GC-MS sample tubes using a handheld pocket pump (SKC $\mathrm{Ltd}, \mathrm{UK}$ ) at a flow rate of $150 \mathrm{~mL} \mathrm{~min}^{-1}$ (total sample time $\sim 43 \mathrm{~min}$ ). Sample tubes were stored at $4{ }^{\circ} \mathrm{C}$ until analysed. VOC quantification was by comparison with commercially available liquid standards (Aldrich, Fluka and Sigma) diluted in methanol. Isoprene quantification was by comparison with a $700 \mathrm{ppbV}$ in $\mathrm{N}_{2}$ certified gas standard (BOC, UK).

$\mathrm{NO}$ and $\mathrm{NO}_{2}$ mixing ratios were measured using a chemiluminescence gas analyser (Model 42i, Thermo Scientific, USA). Ozone was measured using a UV photometric gas detector (Model 49C, Thermo Scientific). 


\subsubsection{Particle phase measurements}

Within the main reaction chamber, a scanning mobility particle sizer (SMPS) system was used to measure the particle size distribution and total aerosol mass concentration (without sample drying). A particle density of $1.3 \mathrm{~g} \mathrm{~cm}^{-3}$ was assumed for calculating the mass of SOA particles in unseeded experiments (Alfarra et al., 2006; Bahreini et al., 2005). For seeded experiments, a density of $1.77 \mathrm{~g} \mathrm{~cm}^{-3}$ was assumed for calculating the ammonium sulfate seed mass and $1.3 \mathrm{~g} \mathrm{~cm}^{-3}$ for calculating the additional SOA mass. A waterbased condensation particle counter (wCPC, TSI 3786) was used to count the total particle number concentration between $2.5 \mathrm{~nm}$ and $\sim 3 \mu \mathrm{m}$. Further instrument details can be found in Alfarra et al. (2012) and references therein.

Real-time broad chemical characterisation of the SOA was made using a compact time-of-flight aerosol mass spectrometer (cToF-AMS; Aerodyne Research, Inc., USA). A detailed description of the instrument, its operation and calibrations can be found elsewhere (e.g. Drewnick et al., 2005; Canagaratna et al., 2007). The instrument was operated in the standard configuration, taking both mass spectrum (MS) and particle time-of-flight (PToF) data, and was calibrated for ionisation efficiency using $350 \mathrm{~nm}$ monodisperse ammonium nitrate particles. The vaporiser was set at approximately $600{ }^{\circ} \mathrm{C}$ and data were collected at a time resolution of $2 \mathrm{~min}$. A collection efficiency value of unity was applied to these data, based on evidence from a previous chamber study (Alfarra et al., 2006).

Filter samples for off-line analysis were collected (without denuders) in a specially constructed holder, positioned in the chamber vent line. Aerosol samples were collected onto $47 \mathrm{~mm}$ quartz fibre filters (Whatman) at a rapid flow rate of $3 \mathrm{~m}^{3} \mathrm{~min}^{-1}$ (sample time $\sim 6 \mathrm{~min}$ ). After sampling, filters were immediately placed in pre-cleaned glass vials and stored below $-20^{\circ} \mathrm{C}$ until analysis. The filter collection procedure employed here is much faster than traditional filter collection methods, which should minimise any potential negative or positive artefacts.

The filters were extracted into high purity water, filtered, evaporated to dryness and redissolved in $1 \mathrm{~mL}$ $50 \% \mathrm{MeOH}: 50 \% \mathrm{H}_{2} \mathrm{O}$. The water-soluble compounds were analysed using liquid-chromatography ion-trap mass spectrometry (LC-MS/MS). Reverse-phase LC separation was achieved using an HP 1100 LC system equipped with an Eclipse ODS-C 18 column with $5 \mu \mathrm{m}$ particle size (Agilent; $4.6 \mathrm{~mm} \times 150 \mathrm{~mm})$. Samples $(60 \mu \mathrm{L})$ were injected then eluted by gradient elution with solvents A: $0.1 \% v / v$ formic acid water and B: methanol (both Optima grade, Fisher Scientific, UK) and a gradient program of $3 \% \mathrm{~B}$ at time $0 \mathrm{~min}$ to $100 \% \mathrm{~B}$ at $60 \mathrm{~min}$ with a flow rate of $0.6 \mathrm{~mL} \mathrm{~min}^{-1}$. Mass spectrometry analysis was performed in negative ionisation mode using an HCT-Plus ion-trap mass spectrometer with electrospray ionisation (Bruker Daltonics $\mathrm{GmbH}$ ). Electrospray ionisation (ESI) was carried out at $350{ }^{\circ} \mathrm{C}$ with a neb- uliser pressure of 4.82 bar and a nitrogen drying gas flow of $12 \mathrm{~L} \mathrm{~min}^{-1}$. Further details can be found in Hamilton et al. (2013).

\subsection{Experimental protocol}

Three plants were placed in the plant chamber a minimum of $48 \mathrm{~h}$ prior to the start of each experiment. Both the pots and soil were isolated by enclosing them in PTFE sheeting; this acted to prevent VOC emissions from the plastic pots and soil $\mathrm{NO}_{\mathrm{x}}$ emissions from entering the chamber air. Three experiments were carried out on each species over a one-week period, after which the plants were removed and replaced with three plants of the next species and the experiment cycle repeated.

Prior to each experiment, ozone was added to the chamber to give a mixing ratio of approximately $2 \mathrm{ppmV}$ and was left overnight. The chamber was then filled and flushed several times using clean air from the facility's main inlet system (including Purafil, charcoal and HEPA filters as described above), until the total particle count (as measured by a water based condensation particle counter) was below $10 \mathrm{~cm}^{-3}$ and the $\mathrm{O}_{3}$ and $\mathrm{NO}_{\mathrm{x}}$ levels were less than 1 and $2 \mathrm{ppbV}$, respectively. At this point, the reaction chamber was flushed and then connected to the plant chamber for filling with the plant VOC emissions, a process carried out in the dark over a period of 1-1.5 h. Aerosol- and gas-phase composition and concentrations were continuously monitored throughout. At the end of the filling process, the plant chamber was disconnected from the reaction chamber, and within $\sim 1 \mathrm{~min}$, the lamps in both chambers were turned on and pure $\mathrm{O}_{3}$ was injected to provide an initial concentration of around 20 or $70 \mathrm{ppbV}$ (experiment dependent). The switching on of the chamber lamps marked the start of each experiment, which typically lasted $6 \mathrm{~h}$ from this point. For experiments using pre-existing seed, polydisperse ammonium sulfate particles (diameter 40-60 nm) were generated from an aqueous solution using an aerosol nebuliser (ATM 230, Topas $\mathrm{GmbH}$, Germany) and injected without drying into the reaction chamber at the end of the filling process from the plant chamber.

In our experiments, we chose to use ammonium sulfate for the aerosol seeds, rather than acidic particles that could otherwise promote isoprenoid particulate mass formation. Whilst it is recognised that isoprenoid SOA mass can be enhanced by the presence of acidic aerosol seed as originally reported by Jang et al., 2002 and subsequently by Limbeck et al., 2003, Edney et al., 2005, Kleindienst et al., 2007 and Surratt et al., 2007, we have limited our study to SOA formation in the mixed precursor systems without deliberate enhancement of particle mass by condensed phase reaction. There is clear evidence that isoprene oxidation can contribute to atmospheric SOA formation (e.g. Claeys et al., 2004a; Edney et al., 2005) and we have previously found that enhancement in SOA from isoprene oxidation above the 
Table 1. List of experiments conducted and their general parameters.

\begin{tabular}{llcccl}
\hline Date & Tree species & $\begin{array}{c}\text { Initial NO} \\
(\mathrm{ppbV})\end{array}$ & $\begin{array}{c}\mathrm{VOC} / \\
\mathrm{NO}_{\mathrm{x}}\end{array}$ & $\begin{array}{c}\text { Relative } \\
\text { humidity }(\%)\end{array}$ & $\begin{array}{l}\text { Pre-existing } \\
\text { seed }\end{array}$ \\
\hline $22 / 06 / 09$ & Ficus benjamina & 3 & 4.2 & 79 & None \\
$23 / 06 / 09$ & Ficus benjamina & 6 & 2.7 & 75 & None \\
$25 / 06 / 09$ & Ficus benjamina & 2 & 6.3 & 65 & Sulfate \\
$29 / 06 / 09$ & Ficus cyathistipula & 2 & 9.4 & 71 & None \\
$30 / 06 / 09$ & Ficus cyathistipula & 2 & 7.8 & 75 & Sulfate \\
$02 / 07 / 09$ & Ficus cyathistipula & 3 & 5.6 & 78 & Sulfate \\
$06 / 07 / 09$ & Betula pendula & 3 & 5.6 & 84 & None \\
$07 / 07 / 09$ & Betula pendula & 3 & 5.5 & 73 & Sulfate \\
$09 / 07 / 09$ & Betula pendula & 2 & 1.5 & 70 & Sulfate \\
$10 / 07 / 09$ & Betula pendula +36 ppbV isoprene & 2 & 5.5 & 70 & Sulfate \\
$13 / 07 / 09$ & Ficus benjamina & 2 & $-*$ & 87 & Sulfate \\
$15 / 07 / 09$ & Ficus benjamina & 3 & $-*$ & 89 & Sulfate \\
$16 / 07 / 09$ & Ficus benjamina +4.5 ppbV limonene & 2 & $-*$ & 85 & None \\
\hline
\end{tabular}

* No quantified VOC data available

Bornean rainforest compared with the Amazon, may result from an enhanced marine acidic sulfate contribution to submicron aerosol (Robinson et al., 2011). Intermediates in SOA formation from isoprene have been identified (e.g. P. Lin et al., 2012; Y. H. Lin et al., 2012) and mechanisms for the acidcatalysed formation have been proposed (Surratt et al., 2010). Whilst outside the scope of the current study, this should be the focus of future work.

Air samples were taken from three separate locations along the airflow path: (1) immediately before the plant chamber (pre-PC) for blank subtraction, (2) immediately after the plant chamber (post-PC) during the reaction chamber filling period for directly emitted BVOCs and (3) from the reaction chamber $(\mathrm{RC})$ during the experiment. $\mathrm{RC}$ air was monitored continuously using PTR-MS and CIR-ToF-MS for VOC decay and formation of reaction products. Air samples from the pre-PC and post-PC positions, as well as RC air samples immediately at the start of each experiment and 1,2, 4 and $6 \mathrm{~h}$ after the lights were switched on, were collected on Tenax TA and Carbotrap filled stainless steel tubes (Supelco, Inc., USA) for GC-MS analysis.

RH $(\%), \mathrm{CO}_{2}(\mathrm{ppmV})$, PAR $\left(\mu \mathrm{mol} \mathrm{m}{ }^{-2} \mathrm{~s}^{-1}\right)$ and temperature $\left({ }^{\circ} \mathrm{C}\right)$ in the plant chamber were recorded every 5 or 10 min during reaction chamber filling, and every 15 or 20 min overnight. System blanks were taken at the start and end of the experimental period. The reaction chamber background was checked and characterised through the performance of regular blank experiments (one in every five experiments). $\mathrm{NO}_{\mathrm{x}}\left(\mathrm{NO}, \mathrm{NO}_{2}\right.$ and $\mathrm{NO}_{3}$ ) and $\mathrm{O}_{3}$ were continuously monitored in the reaction chamber. A list of all experiments and their general parameters are given in Table 1.

\subsection{Calculated $\mathrm{OH}$ concentrations}

Since isoprene losses are controlled by reaction with ozone and the hydroxyl radical $(\mathrm{OH})$, the concentration of $\mathrm{OH}$ available to react with isoprene in the reaction chamber for each experiment was calculated based on the measured concentrations of $\mathrm{O}_{3}$ and isoprene in each experiment, the rate of change in isoprene concentration, and the rate constants for the reactions of isoprene with $\mathrm{OH}$ and $\mathrm{O}_{3}$, using Eq. (1):

$$
\frac{\frac{d[\text { isoprene }]}{d t}+k_{\mathrm{O}_{3}}\left[\mathrm{O}_{3}\right][\text { isoprene }]}{-k_{\mathrm{OH}}[\text { isoprene }]}=[\mathrm{OH}] .
$$

Hourly averaged concentrations of $\mathrm{O}_{3}$ and isoprene were calculated for five of the experiments using the tropical fig. Using these data along with Eq. (1), a range of $\mathrm{OH}$ concentrations were obtained. For the first hour after lights on, $[\mathrm{OH}]$ was estimated to be $1.9 \times 10^{5}-9.5 \times 10^{5}$ molecules $\mathrm{cm}^{-3}$, whereas towards the end of the experiment after $\sim 5 \mathrm{~h}$, values of $8.1 \times 10^{5}-1.9 \times 10^{6}$ molecules $\mathrm{cm}^{-3}$ were obtained. In general, during the tropical fig experiments, $[\mathrm{OH}]$ estimated from isoprene and ozone was observed to increase steadily over the duration of the experiment from 0 to $5 \mathrm{~h}$ after lights on.

\subsection{VOC / $\mathrm{NO}_{\mathrm{x}}$ conditions}

Figure 1 shows the time-dependent mixing ratios of ozone and oxides of nitrogen for each experiment set. Although every effort was made to keep the concentrations of oxides of nitrogen low, measurable amounts were present, giving initial VOC $/ \mathrm{NO}_{\mathrm{x}}$ ratios of the order of 2-6 and 3-9 (see Table 1) for the birch and fig experiments, respectively (where the VOC concentration is equal to the sum of all potential precursor concentrations). In terms of a "Sillman plot" (Sill- 
Table 2. GC-MS identification of BVOCs present in the plant chamber air immediately before RC filling began. Quantification of isoprene, total monoterpenes and total sesquiterpenes was carried out using PTR-MS and CIR-ToF-MS (see Figs. 2 and 5).

\begin{tabular}{|c|c|c|c|c|}
\hline \multirow[t]{2}{*}{ Experiment } & \multicolumn{4}{|c|}{ Compounds detected by GC-MS (abundance ppbV) (“trace” means < $0.1 \mathrm{ppbV}$ ) } \\
\hline & Isoprene & $\begin{array}{l}\text { Monoterpenes } \\
\text { (and related) }\end{array}$ & Sesquiterpenes & Other \\
\hline B. pendula & $\begin{array}{l}\text { Yes } \\
(0.25-1.19)\end{array}$ & $\begin{array}{l}\alpha \text {-pinene }(0.31-1.08) \\
\beta \text {-pinene }(0.74-7.19) \\
\text { ocimene (trace-1.22) } \\
\Delta 3 \text {-carene }(1.89-4.94) \\
\gamma \text {-terpinene (trace) } \\
2,4,6 \text {-octatriene,2,6-dimethyl } \\
\text { (trace) } \\
4,7 \text {-methano-1H-indene, octahy- } \\
\text { dro (trace) } \\
\text { linalool (trace) }\end{array}$ & $\begin{array}{l}\beta \text {-caryophyllene }(0.15-0.22) \\
\alpha \text {-farnesene }(0.14) \\
\alpha \text {-caryophyllene }(0.59-0.92) \\
\alpha \text {-copaene (trace) } \\
\text { aromadendrene }(0.45-0.51) \\
\alpha \text {-cedrene (trace) } \\
\alpha \text {-pyronene (trace) }\end{array}$ & $\begin{array}{l}\text { acetaldehyde (trace) } \\
\text { caryophyllene-epoxide } \\
\text { (trace) } \\
\text { nerolidol (trace) }\end{array}$ \\
\hline F. benjamina & $\begin{array}{l}\text { Yes } \\
(38.49)\end{array}$ & $\begin{array}{l}\alpha \text {-pinene (trace) } \\
\text { limonene (trace) } \\
\text { sabinene (trace) } \\
\text { linalool (trace) }\end{array}$ & $\alpha$-cubebene (trace) & $\begin{array}{l}\text { acetaldehyde (trace) } \\
\text { benzoquinone (trace) } \\
\text { pyridine (trace) } \\
\text { methyl salicyclate } \\
\text { (trace) } \\
\text { decanal (trace) }\end{array}$ \\
\hline F. cyathistipula & Yes (75.08) & $\begin{array}{l}\alpha \text {-pinene (trace) } \\
\beta \text {-pinene (trace) } \\
\text { limonene (trace) }\end{array}$ & $\beta$-caryophyllene (trace) & acetic acid (trace) \\
\hline $\begin{array}{l}\text { Mixed canopy } \\
\text { F. benjamina } \\
\text { F. cyathistipula } \\
\text { C. millis }\end{array}$ & Yes & $\begin{array}{l}\alpha \text {-pinene }(0.37) \\
\text { camphene }(0.11) \\
\text { limonene }(0.42) \\
\text { ocimene (trace) }\end{array}$ & None detected & $\begin{array}{l}p \text {-dichlorobenzene } \\
\text { methyl salicyclate }\end{array}$ \\
\hline
\end{tabular}

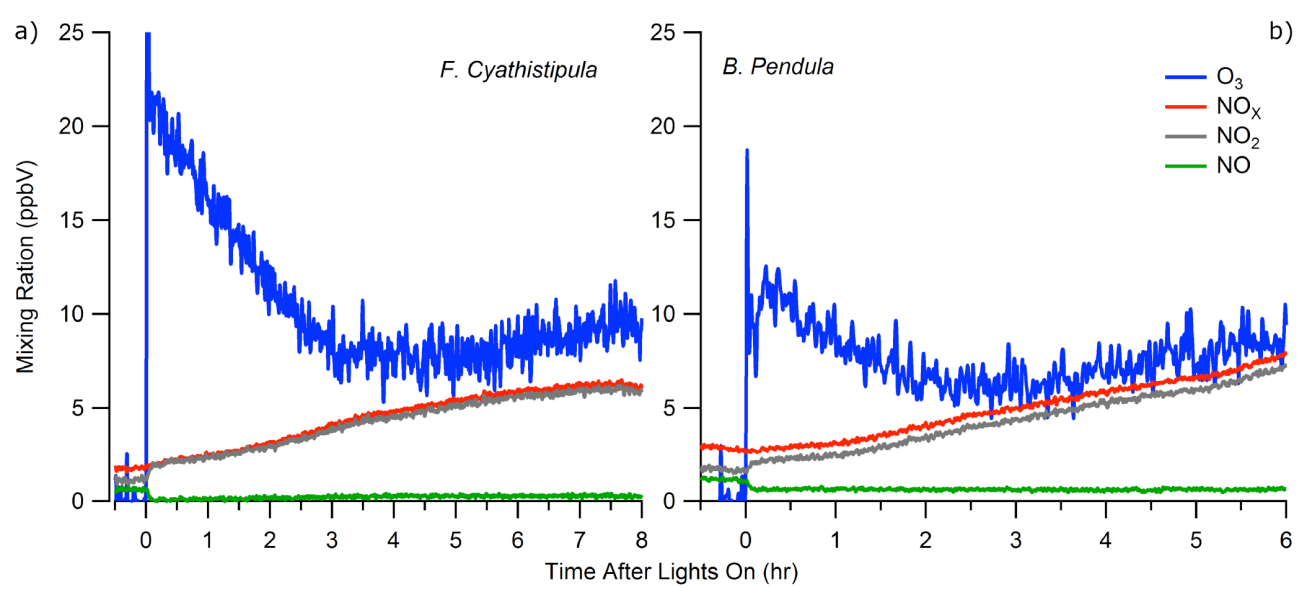

Figure 1. Temporal evolution of $\mathrm{NO}, \mathrm{NO}_{2}, \mathrm{NO}_{\mathrm{x}}$ and $\mathrm{O}_{3}$ during typical Ficus cyathistipula (a) and Betula pendula (b) experiments (25 June and 7 July 2009, respectively).

man, 1999), the experiments were carried out in the "VOCsensitive regime."

The absolute concentration of VOCs in the reaction chamber was roughly ten times greater than those measured over the rainforest during our field experiments (MacKenzie et al., 2011) and the VOC $/ \mathrm{NO}_{\mathrm{x}}$ ratios employed here were as much as ten times lower (i.e. typical isoprene: $\mathrm{NO}_{\mathrm{x}}$ ratio of $20: 1$ over the rainforest; see Hewitt et al., 2010). The source 

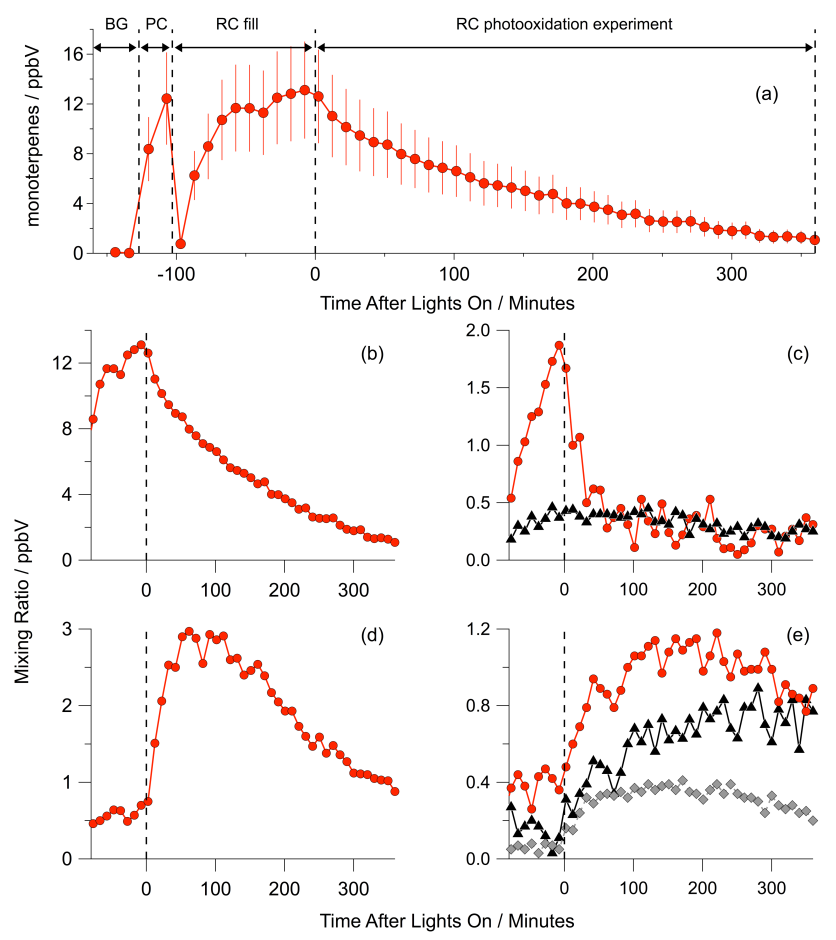

Figure 2. Temporal evolution of a series of precursor compounds and their oxidation products, as observed in the main reaction chamber during a typical Betula pendula experiment (7 July 2009). Plot (a) shows the entire experiment process in terms of monoterpene evolution, from background (BG) and plant chamber (PC) measurements, to reaction chamber $(\mathrm{RC})$ fill and the main photo-oxidation experiment within the reaction chamber. (b) shows monoterpene evolution, (c) shows sesquiterpenes (red circles and lines) and camphor (black triangles and lines), (d) $\Sigma\left(I_{111}, I_{93}\right)$ and (e) the primary ketone $(m / z$ 139) (red circles and lines), primary ketoaldehyde $(m / z 107+151+169)$ (black triangles and lines) and methyl vinyl ketone (MVK) + methacrolein (MACR) $(\mathrm{m} / z$ 71) (grey diamonds and dashed line).

of the $\mathrm{NO}_{\mathrm{x}}$ in the reaction chamber (initially $\sim 2-6 \mathrm{ppbV}$ $\mathrm{NO}_{\mathrm{x}}$, but increasing to $\sim 5-9 \mathrm{ppbV}$ after $\sim 5 \mathrm{~h}$ ) is attributed to a small amount of diffusion of outside ambient air across the porous Teflon membrane into the reaction chamber. The production of certain reactive intermediates in the oxidation of VOCs (e.g. hydroxyl hydroperoxides from isoprene oxidation) is very sensitive to $\mathrm{NO}_{\mathrm{x}}$ concentrations in the reaction mixture.

\section{Results}

\subsection{Experiments with Betula pendula}

\subsubsection{Gas phase}

Continuous gas-phase monitoring with CIR-ToF-MS and PTR-MS throughout the experiments indicated successful

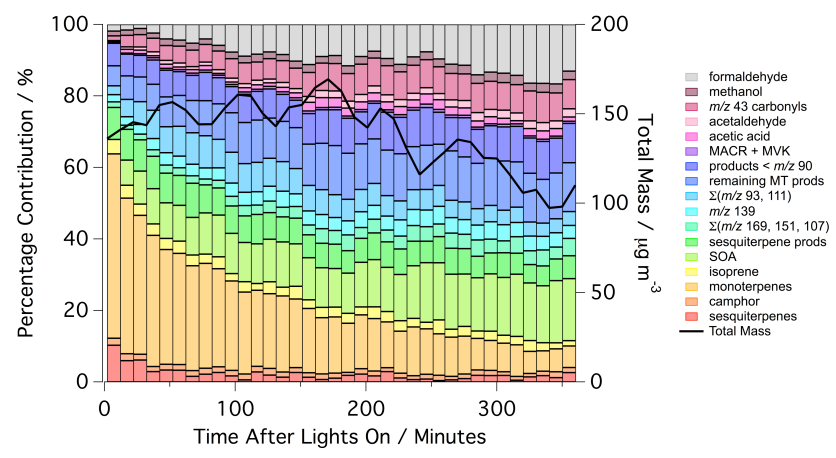

Figure 3. Evolution of measured mass through the Betula pendula system (7 July 2009), showing the relative contribution of precursor compounds, oxidation products and SOA mass to total measured mass, with time (coloured bars, left axis) and total measured mass with time (black line, right axis). Note: ammonium sulfate seed mass removed from the SOA mass concentration.

transfer of VOC precursor material from the plant chamber to the reaction chamber prior to lights on. The data indicated that there was negligible loss of precursor compounds during the chamber transfer process (Fig. 2a).

Immediately after initiation of the photochemistry, the VOC precursor concentrations were observed to decay and product ions began to appear in the CIR-ToF and PTR mass spectra. Approximately 60 product-ion peaks were observed by CIR-ToF-MS and PTR-MS in the organic gas phase during a typical Betula pendula experiment. The temporal profiles of a number of the most abundant OVOCs measured are shown in Fig. 2. From a combination of the CIR-ToF-MS, PTR-MS and GC-MS observations (and from those observations discussed below for the tropical plant experiments), over 50 different hemi-, mono- and sesquiterpene oxidation products were tentatively identified (Fig. 3 and Tables S1-S5 in the Supplement).

From initial inspection of the data, it is clear that monoterpenes dominate during the Betula pendula experiments (Fig. 2a and b), with strong signals observed in the CIR-ToF and PTR mass spectra at $m / z 137$ (protonated parent ion) and 81 (hydrocarbon fragment). A small amount of isoprene was also detected during Betula pendula experiments; however, this was always significantly lower in magnitude than the sum of monoterpenes; for example, during the experiment on 7 July $2009,12.6( \pm 3.8)$ ppbV monoterpenes were measured in the reaction chamber prior to lights on (cf. $11.4 \mathrm{ppbV}$ total monoterpenes measured at the post-PC position by GCMS), whereas only $2.0( \pm 1.0) \mathrm{ppbV}$ isoprene was detected. Speciation of the monoterpenes by GC-MS indicated that the most dominantly emitted $\mathrm{C}_{10}$ compounds from Betula pendula were $\alpha$ - and $\beta$-pinene (Table 2).

$\mathrm{C}_{15}$ sesquiterpenes (parent ion $\mathrm{m} / z$ 205) were detected in the plant and reaction chambers during each Betula pendula experiment, with the most abundant species identified by GC-MS being $\beta$-caryophyllene (Table 2). Sesquiterpenes 
were also measured in the reaction chamber by CIR-ToF-MS (Fig. 2c); however, for the majority of the experiments they were present at concentrations either close to or below the detection limit, hence they could not always be monitored as a function of reaction time. For the experiment on 7 July 2009, $1.7( \pm 0.9)$ ppbV sesquiterpenes were measured by CIR-ToFMS prior to lights on (cf. $2.2 \mathrm{ppbV}$ total sesquiterpenes measured at the post-PC position by GC-MS). An ion of $m / z 153$ was also observed in the PTR and CIR-ToF mass spectra of the plant chamber emissions and subsequently in the reaction chamber air, tentatively assigned (and hereafter referred to) as camphor.

During the reaction phase of the Betula pendula experiments the CIR-ToF mass spectra were dominated by ions of relatively high mass $(m / z>100)$ pertaining to products of both monoterpene and sesquiterpene oxidation. The ions of highest mass $(m / z, 170-290)$ are characteristic of sesquiterpene oxidation, and have been observed recently during a similar chamber study investigating $\beta$-caryophyllene photooxidation (Jenkin et al., 2012). Drawing a comparison between these data and the detailed $\beta$-caryophyllene study conducted by Jenkin et al. (2012), a number of tentative assignments have been made for $\beta$-caryophyllene products, with the assumption that other precursor-specific structural isomers may also occupy the same mass channels. A full list of example tentative assignments is given in the supplementary information (Table S2 in the Supplement). The sum of all sesquiterpene products measured in the chamber was estimated to be $\sim 1.5 \mathrm{ppbV}$ (assuming an average PTR sensitivity for such high-mass, oxygenated compounds).

In contrast to the small amounts of sesquiterpene products observed in the reaction chamber, the products observed in greatest abundance were those derived from monoterpene decay. The largest (combined) product signal measured by the CIR-ToF-MS was that of $\Sigma\left(I_{111}, I_{93}\right)$, where $I_{x}$ is the intensity of the mass spectrum at $m / z=x$ (Fig. 2d). Previously, the $m / z 111$ and 93 signals have been shown to correspond to various primary $\mathrm{C}_{7}$ unsaturated aldehydes formed during the oxidation of unsaturated acyclic monoterpenes, such as myrcene, ocimene and linalool (Lee et al., 2006a, b; $\mathrm{Ng}$ et al., 2006; Wyche et al., 2014). In the case of myrcene and ocimene, the $\mathrm{m} / \mathrm{z}, 111$ and 93 signals correspond to the parent ion $\left(\mathrm{MH}^{+}\right)$and the dehydrated daughter fragment $\left(\mathrm{MH}^{+} \cdot \mathrm{H}_{2} \mathrm{O}\right)$ respectively, while in the case of linalool, $m / z 111$ corresponds to the dehydrated daughter ion and $m / z 93$ is a further fragment. The concomitant $m / z 111$ and 93 signals have also been reported to result from a $C_{7}$ cyclic ketone formed during the oxidation of terpinolene (not found in the Ficus emission profile and $<1 \mathrm{ppbV}$ found in the Betula profile). The $m / z 111$ and 93 ions have previously been observed to be significant contributors to total ion signal in the PTR mass spectra during single-precursor chamber experiments with concomitant SOA formation (Lee et al., 2006a, b; Ng et al., 2006; Wyche et al., 2014), and the $m / z 111$ ion has also been observed in ambient air measurements over a forested region (Holtzinger et al., 2005).

As can be seen from Fig. 2 d, the $\Sigma\left(I_{111}, I_{93}\right)$ signal rises rapidly during the initial stages of the experiment, much more so than other monoterpene oxidation products (cf. Fig. 2e), suggesting that the precursor has a much shorter lifetime with respect to $\mathrm{OH}$ and $\mathrm{O}_{3}$. Of those monoterpenes speciated by GC-MS, ocimene and linalool have the shortest lifetimes, with $k_{\mathrm{OH}}=3.04$ and $1.6 \times 10^{-10} \mathrm{~cm}^{3}$ molecule $\mathrm{s}^{-1} \mathrm{~s}^{-1}$ (average lifetimes with respect to $\mathrm{OH} \sim 44$ and $\sim 55 \mathrm{~min}$ ), respectively, compared to $k_{\mathrm{OH}}=7.4 \times 10^{-11} \mathrm{~cm}^{3}$ molecule $\mathrm{e}^{-1} \mathrm{~s}^{-1}$ for $\beta$-pinene (average lifetime with respect to $\mathrm{OH} \sim 1458 \mathrm{~min}$ ) (Atkinson and Arey, 2003; Kim et al., 2011). The $\Sigma\left(I_{111}, I_{93}\right)$ signal peaks at around $60-100 \mathrm{~min}$ at $3.0( \pm 0.7) \mathrm{ppbV}$ (concentration estimated using pinonaldehyde sensitivity), before decaying at a greater rate than that of the precursor monoterpenes and the other monoterpene products. This relatively short lifetime gives further insight into the potential identity of the $m / z 111$ and 93 signals, perhaps indicating the presence of multiple $\mathrm{C}=\mathrm{C}$ bonds in the hydrocarbon structure, as would be found in the primary $\mathrm{C}_{7}$ aldehydes obtained from the oxidation of ocimene or myrcene for example. Other short-lived biogenic oxidation products that could exist in such mesocosm systems include $\alpha$-hydroxy carbonyls, similarly formed following $\mathrm{OH}$ addition to a $\mathrm{C}=\mathrm{C}$ bond.

Other dominant signals observed by PTR-MS and CIRToF-MS during oxidation of the Betula pendula air matrix include the sum of $m / z 169,151$ and 107, which respectively correspond to the parent ion and two daughter fragments of a number of primary monoterpene ketoaldehydes (which, from the speciated monoterpene plant chamber data, are most likely to be pinonaldehyde, caronaldehyde and $\alpha / \gamma$-terpinaldehyde); and $m / z$ 139, corresponding to the parent ion of a number of primary monoterpene ketones (most likely to be nopinone and $\Delta 3$-carene primary ketone, again when considering the monoterpenes speciated by GCMS). As shown in Fig. 2e the primary ketoaldehyde and ketone signals had similar temporal profiles to one another, growing at a slower rate than that of $\Sigma\left(I_{111}, I_{93}\right)$, to peak concentrations of around $0.9( \pm 0.3)$ and $1.2( \pm 0.3) \mathrm{ppbV}$, respectively, as the monoterpene trace tended towards zero. The temporal profile for the sum of all other "monoterpenelike" product ions (i.e. ions of $m / z>90$ ) was very similar to those of the primary ketoaldehyde(s) and ketone(s), peaking at a combined mixing ratio of approximately $3.5 \mathrm{ppbV}$ (assuming an average PTR sensitivity for such high-mass, oxygenated compounds).

During the oxidation of compounds emitted by Betula pendula, the primary isoprene products methyl vinyl ketone (MVK) and methacrolein (MACR) (measured together at $m / z$ 71) were observed to evolve in the same manner as the primary monoterpene ketoaldehyde(s) and ketone(s), peaking at an approximate mixing ratio of $0.4( \pm 0.1) \mathrm{ppbV}$ (Fig. 2e). A series of lower- $m / z$ ions were also observed 


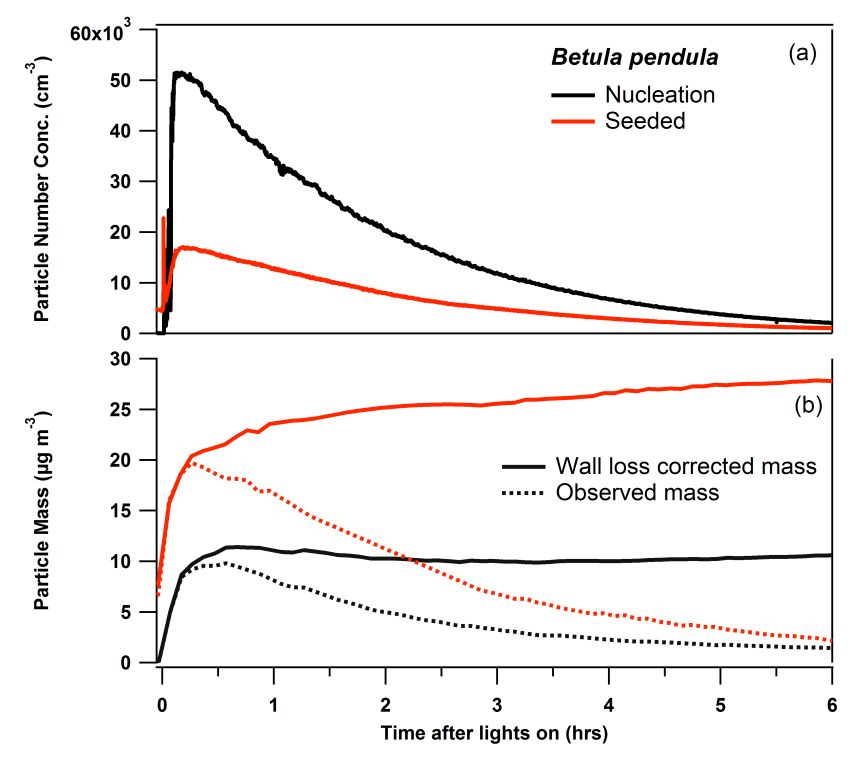

Figure 4. Particle numbers and mass concentrations measured during nucleation (6 July 2009) and ammonium sulfate-seeded (7 July 2009) Betula pendula experiments (a). In (b), both the measured (dashed lines) and wall loss-corrected (solid lines) mass concentrations are shown.

to evolve within the reaction chamber, including $\mathrm{m} / \mathrm{z} 61$ (acetic acid), 59 (acetone), 47 (formic acid), 45 (acetaldehyde), 33 (methanol) and 31 (formaldehyde). Each of these compounds has previously been associated with monoterpene oxidation and/or off-gassing from illuminated chamber walls. Methanol, acetone and $m / z 99$ (potentially cis3-hexenal) were also observed within the reaction chamber prior to lights on, with a combined mixing ratio of approximately $20 \mathrm{ppbV}$.

\subsubsection{Particle phase}

From inspection of the wCPC and SMPS data we see that SOA mass formed during oxidation of the Betula pendula air matrix. As can be seen from Fig. 4, during unseeded experiments nucleation occurred immediately after lights on, with no induction period prior to mass formation. After nucleation, SOA mass increased rapidly to $\sim 11 \mu \mathrm{g} \mathrm{m}^{-3}$ by $\sim 40$ min (experiment 6 July 2009), followed by a relatively stable plateau (after the application of wall loss corrections) and a slight increase towards the end of the experiment. In order to suppress nucleation, seed particles were introduced in some experiments, as has been used previously (Dommen et al., 2009; Meyer et al., 2009; Surratt et al., 2007; Kleindienst et al., 2006; Carlton et al., 2009). This more closely represents the conditions encountered in the ambient atmosphere where there is pre-existing aerosol. Consistent with the nucleation experiments described above, SOA mass was observed to increase as soon as the photochemistry was ini- tiated when an ammonium sulfate seed was present (Fig. 4, experiment 7 July 2009).

Using the wall loss-corrected mass data, along with the corresponding quantity of the sum of precursor species reacted and Eq. (2), SOA yields were obtained for the Betula pendula oxidation system:

$Y_{\mathrm{SOA}}=\frac{M_{\mathrm{p}}}{\Delta\left(\sum \mathrm{VOC}\right)}$

In this instance, $Y_{\mathrm{SOA}}=\mathrm{SOA}$ mass yield, $M_{\mathrm{p}}=$ peak SOA mass $\left(\mu \mathrm{g} \mathrm{m}^{-3}\right)$ and $\Delta(\Sigma \mathrm{VOC})=$ the sum of gas-phase precursors reacted by the time $M_{\mathrm{p}}$ is reached $\left(\mu \mathrm{g} \mathrm{m}^{-3}\right.$ ) (Odum et al., 1997). In order to determine $\Delta(\Sigma$ VOC $)$, the timedependent VOC mixing ratios for total sesquiterpenes, total monoterpenes, camphor and isoprene were independently converted to their corresponding mass concentrations $\left(\mu \mathrm{g} \mathrm{m}^{-3}\right)$ and the four data sets were combined to give a "total" VOC precursor decay profile. From the total VOC profile $\Delta(\Sigma$ VOC $)$ was calculated, using the starting mass of $\Sigma$ VOC at time $=0$ and the mass of $\Sigma \mathrm{VOC}$ at the time of $M_{\mathrm{p}}$. The uncertainty in $\Delta(\Sigma \mathrm{VOC})$ is estimated to be $\pm 41 \%$. Using Eq. (2) for the two Betula pendula experiments for which both gas-phase mixing ratio and wall loss-corrected aerosol data were available, SOA yield values of 39 and $26 \%$ were obtained (Fig. 4). It should also be noted that along with previous caveats made regarding the role of the chamber walls and other measurement uncertainties, these yield values also do not take into account the potential loss of particularly "sticky" low-volatility compounds (e.g. Ehn et al., 2014) to internal surfaces of the chamber.

It should be noted that the partitioning of material between the vapour phase and chamber walls has not been taken into account in the above yield calculations. Matsunaga and Ziemann (2010) showed that semivolatile organic compounds move towards equilibrium between the walls and the vapour phase and that the equilibration timescale and equivalent absorptive mass of the walls was dependent on the molecular properties of the partitioning species. Kokkola et al. (2013) demonstrated in their model study that OVOC wall losses will have significant implications on their partitioning between the gas and particle phase, such that the mass components of very low volatility will be almost completely depleted to the chamber walls during the experiment while the depletion of OVOCs of higher volatilities is less efficient. The implications of such partitioning to chamber walls are such that comparison between any yields determined experimentally in different chambers should be conducted with caution. Even when calculated from experiments in the same chamber, yields should be interpreted qualitatively and relatively and not extrapolated to the atmosphere. 


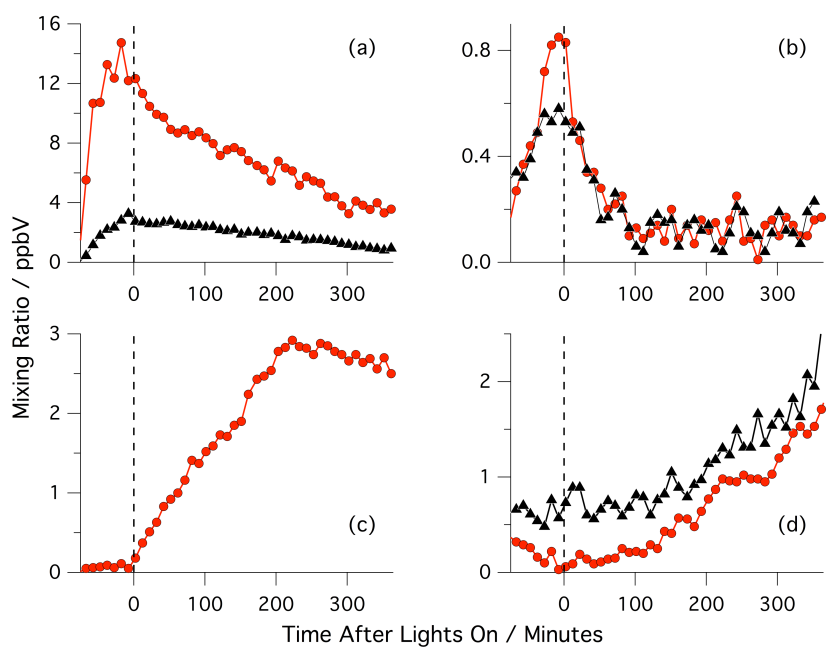

Figure 5. Temporal evolution of a series of precursor compounds and their oxidation products, as observed in the main reaction chamber during a typical Ficus benjamina experiment (23 June 2009). Plot (a) shows isoprene (red circles and lines) and camphor (black triangles and lines) evolution, (b) shows monoterpenes (red circles and lines) and sesquiterpenes (black triangles and lines), (c) MVK + MACR $(\mathrm{m} / \mathrm{z}, 71)$ and (d) $\Sigma$ (monoterpene products) (black triangles and lines) and $\Sigma$ (non-MVK + MACR isoprene products) (red circles and lines).

\subsection{Experiments with tropical species}

\subsubsection{Gas phase}

In order to study the contrast between species that primarily emit monoterpenes and those that primarily emit isoprene, and hence to better understand the isoprene-SOA system, the coupled plant chamber-reaction chamber system was employed to study several tropical species. Two species of fig and one species of palm were selected during the preexperiment screening process. Those experiments using the figs, Ficus cyathistipula and Ficus benjamina gave the most complete data set; hence their results are used as a focus for discussion.

Figure 5 shows the temporal evolution of a number of isoprenoids detected in both the plant and reaction chambers ( $a$ and $b$ ) and the concomitant evolution of a selection of isoprenoid oxidation products (c and d) during a typical $\mathrm{Fi}$ cus benjamina experiment (23 June 2009). Approximately 30 precursor and product-ion peaks were observed during a typical Ficus benjamina experiments by CIR-ToF-MS and PTRMS in the gas phase. Tentative product identification is reported in the supplementary information (Fig. 6, Tables S1S5). A similar set of ions was observed during a typical Ficus cyathistipula experiment.

From inspection of Fig. 5a and b, the dominance of isoprene in the Ficus benjamina system is clear, with $12.3( \pm 4.1) \mathrm{ppbV}$ isoprene detected in the reaction cham-

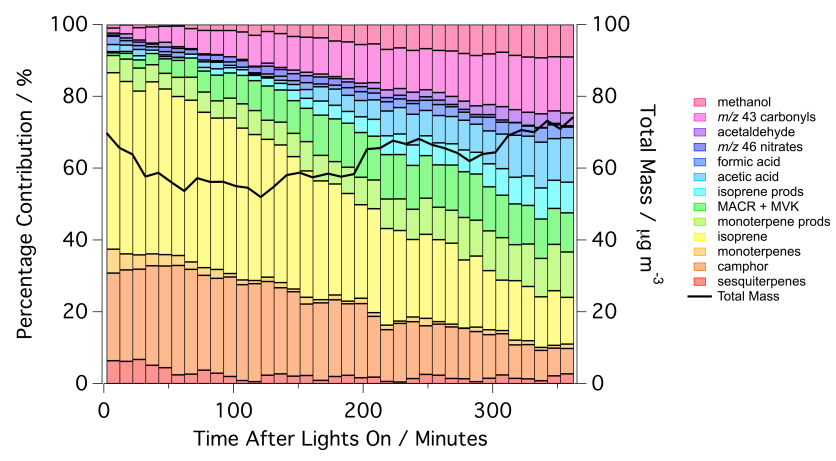

Figure 6. Evolution of measured mass through the Ficus benjamina system (23 June 2009), showing the relative contribution of precursor compounds and oxidation products to total measured mass, with time (coloured bars, left axis) and total measured mass (i.e. $\Sigma$ VOCs + SOA) with time (black line, right axis).

ber at lights on, compared to $0.8( \pm 0.4) \mathrm{ppbV}$ monoterpenes, $0.5( \pm 0.9) \mathrm{ppbV}$ sesquiterpenes and an estimated $2.7( \pm 0.6) \mathrm{ppbV}$ camphor. Speciation of the monoterpenes by GC-MS indicated that the most dominantly emitted $\mathrm{C}_{10}$ compounds for Ficus benjamina were $\alpha$-pinene, limonene, sabinene and linalool and for Ficus cyathistipula were $\alpha$ pinene, $\beta$-pinene and limonene (Table 2). The sesquiterpenes $\beta$-caryophyllene and $\alpha$-cubebene were also identified.

Products of isoprene were observed to dominate the evolving Ficus benjamina and Ficus cyathistipula oxidation systems, with the isobaric primary species MACR and MVK comprising the strongest signals (measured together at $m / z$ 71). For example, during the Ficus benjamina experiment of 23 June 2009, a combined peak MACR + MVK mixing ratio of $2.9( \pm 0.7) \mathrm{ppbV}$ was observed (Fig. 5c).

Along with MACR and MVK, a series of other ions also associated with isoprene oxidation were detected during Ficus benjamina oxidation, including $\mathrm{m} / \mathrm{z}, 117$ and 99 (4-hydroxy-2-methyl-but-2-enoic acid), 103 (C5-alkene diols, C4-hydroxydialdehydes and peroxy methacryloyl nitrate or MPAN: peroxymethacrylic nitric anhydride), 87 (C4-hydroxycarbonyls and methacrylic acid), 83 (e.g. 3methyl furan), 75 (hydroxy acetone) and 31 (formaldehyde). Additionally, a signal of $\mathrm{m} / z 101$ was also measured, possibly corresponding to the sum of a series of C5hydroxycarbonyls and C5-hydroxy hydroperoxides (Tuazon and Atkinson, 1990; Paulson and Seinfeld, 1992; Jenkin et al., 1997; Benkelberg et al., 2000; Sprengnether et al., 2002; Zhao et al., 2004; Surratt et al., 2006; http://mcm.leeds.ac. uk/MCM, v3.1). Of the signals observed, those of $m / z 83$ and 87 (tentatively assigned to be 3-methyl furan and C4hydroxycarbonyls/methacrylic acid respectively), were the greatest in magnitude after MACR + MVK (Fig. 6). The temporal evolution of the sum of all of these products suggests that they are predominantly secondary in nature, forming in the chamber after MACR and MVK. They continued to 


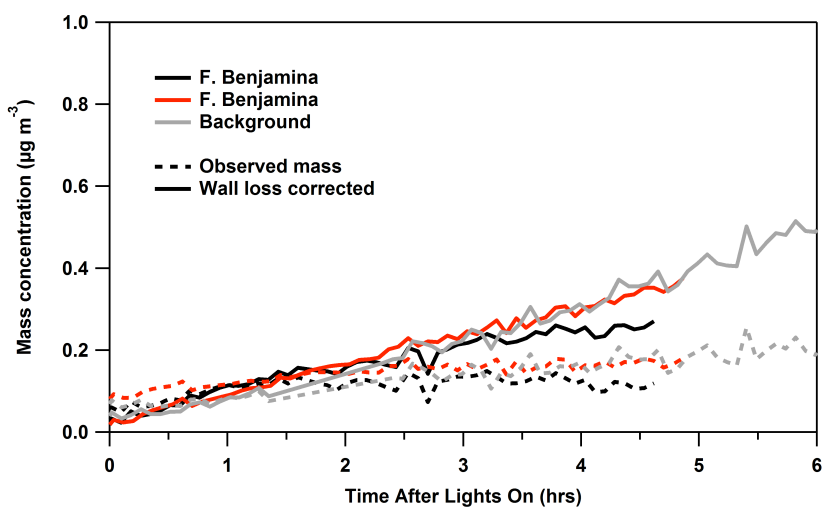

Figure 7. Observed and wall loss-corrected particle mass concentrations during unseeded Ficus benjamina (22 and 23 June 2009) and chamber background (26 June 2009) experiments. The reaction chamber was filled with plant chamber air over a period of $1-1.5 \mathrm{~h}$. Chamber filling was carried out in the dark. Ozone was added immediately prior to lights on. Time begins at the point at which the reaction chamber was illuminated, then increments in hours after lights on.

increase in magnitude as the isoprene signal decreased and as the MACR + MVK signal began to fall (Figs. 5 and 6). During a typical Ficus benjamina experiment, the sum of these isoprene products was estimated to reach a peak mixing ratio of $\sim 1.7 \mathrm{ppbV}$.

A series of lower molecular weight ions were also observed to evolve within the reaction chamber, including $\mathrm{m} / \mathrm{z} 61$ (acetic acid), 47 (formic acid), 45 (acetaldehyde), 33 (methanol) and 31 (formaldehyde). Each of these compounds has previously been associated with isoprene oxidation and/or with off-gassing from illuminated chamber walls. The $m / z 43$ and 46 signals, indicative of carbonyls and nitrates respectively, were also observed to increase significantly during photo-oxidation, indicating the formation and evolution of such species over time during the experiment.

Besides ions pertaining to the oxidation products of isoprene, a number of spectral features typically derived from monoterpene oxidation products were also observed to form and evolve in the reaction chamber, including, $m / z$ 151, 125 , 109, 107, 93 and 91. To a first-order approximation, the total peak quantity of oxidation products not believed to result from isoprene decay was estimated to be of the order of 2 ppbV. However, it should be noted that the isobaric interference present in such a complex system, uncharacterised fragmentation, detection limits and the use of pseudo and averaged calibration sensitivities impose a certain level of unknown uncertainty upon this final value.

\subsubsection{Particle phase}

Contrary to the immediate and abundant formation of new particles in the unseeded Betula pendula experiments, the total number of particles and total aerosol mass did not in-

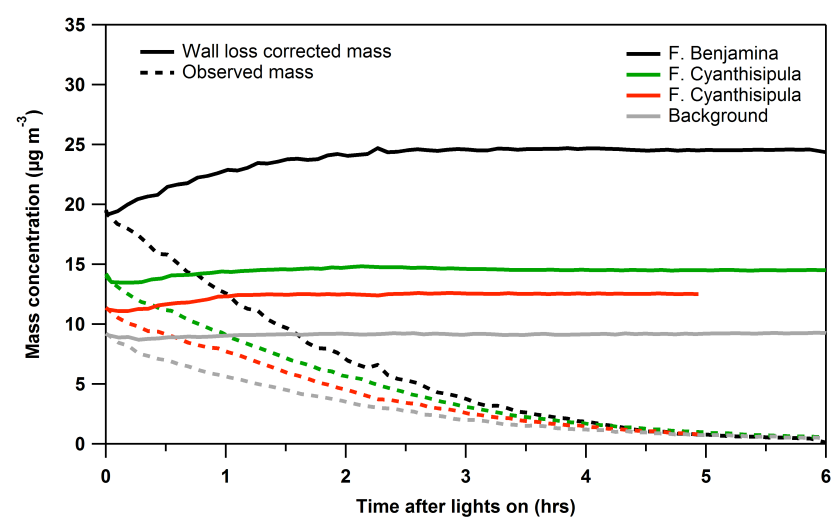

Figure 8. Observed and wall loss-corrected particle mass concentrations during ammonium sulfate-seeded Ficus benjamina (15 July 2009) and Ficus cyathistipula (30 June and 2 July 2009) as well as chamber background (3 July 2009) experiments. Ozone and ammonium sulfate seed were added immediately prior to lights on.

crease above background levels after lights were turned on in the unseeded tropical Ficus benjamina experiments. Figure 7 shows the observed and wall loss-corrected particle mass concentration during two typical Ficus benjamina experiments (22 and 23 June 2009) along with a chamber background experiment. Owing to a lack of particle nucleation in these experiments, the total particle number concentration was too low for the wall loss correction (described in Sect. 2.3) to be implemented. Instead, the average of the wall loss constants determined for the seeded experiments was used to calculate the wall loss corrected mass concentrations reported in Fig. 7.

Figure 8 shows the observed and wall loss-corrected particle mass concentration for ammonium sulfate-seeded experiments using VOC emissions of Ficus benjamina and Ficus cyathistipula, as well as a seeded background experiment. The mass at the start of the experiment represents the initial ammonium sulfate mass. In order to quantify the formation of SOA mass during these experiments, the mass increase relative to the starting seed mass was determined in Fig. 9 by subtracting the initial ammonium sulfate seed mass from the total wall loss-corrected mass. The same calculation was also performed for the Betula pendula seeded experiment (7 July 2009). In contrast to the unseeded Ficus benjamina and Ficus cyathistipula experiments, SOA mass was observed to form when a seed was present in the reaction chamber. The calculated SOA traces in Fig. 9 illustrate a slower build-up of mass during the isoprene-dominated Ficus benjamina (15 July 2009) and Ficus cyathistipula (30 June 2009 and 2 July 2009) experiments compared to the much faster SOA mass formation in the monoterpene-dominated Betula pendula experiment. Peak masses of the order of $1.3-5.5 \mu \mathrm{g} \mathrm{m}^{-3}$ were observed, which when employed with the methodology described in Sect. 3.1.2, produce SOA yields of 10 and $14 \%$ for each of the two Ficus cyathistipula experiments for which 


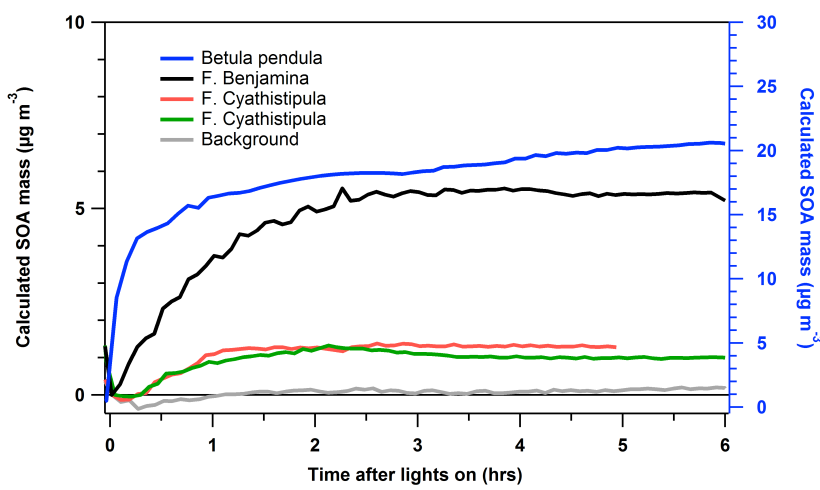

Figure 9. Calculated SOA mass concentrations during ammonium sulfate-seeded experiments for Betula pendula (7 July 2009), Ficus benjamina (15 July 2009) and Ficus cyathistipula (30 June and 2 July 2009). See text for details.

both gas and wall loss-corrected aerosol data were available, 30 June 2009 and 2 July 2009, respectively (Fig. 9). Uncertainty in $\Delta(\Sigma$ VOC $)$ is estimated to be $\pm 47 \%$ and in the size distribution measurements used in the wall loss calculations, of the order of $\pm 2 \%$. The uncertainties in the wall loss correction will likely be substantially greater, but remain unquantified at present.

\section{Discussion and conclusions}

\subsection{Betula pendula}

In this study, we coupled a plant chamber to a photochemical reaction chamber in order to investigate SOA production from a biogenically consistent mixture of biogenic volatile organic compounds. We studied silver birch (Betula pen$d u l a$ ), which emits predominantly monoterpenes, with some sesquiterpenes and oxygenated VOCs but only trace isoprene (Table 2, Fig. 3).

Our Betula pendula experiments showed significant SOA formation (Fig. 4) in both the presence and the absence of an ammonium sulfate seed, and reproduced the rate of production and growth of SOA observed in earlier published studies (Mentel et al., 2009; Carlton et al., 2009; e.g. VanReken et al., 2006; Hallquist et al., 2009; Kiendler-Scharr et al., 2009a, b).

The SOA yield values of $39 \%$ and $26 \%$ obtained here for Betula pendula compare reasonably well with those reported within the literature for single-precursor work conducted under similar conditions. For instance, for the two most abundant monoterpenes emitted by Betula pendula, $\alpha$-pinene and $\beta$-pinene, single-precursor yields of the order 1-43 (16) \% and 3-30\%, respectively, have been observed (values given in parenthesis were obtained from the Manchester aerosol chamber). Similarly, for other common monoterpenes such as limonene, myrcene, $\Delta 3$-carene and $\alpha$ -

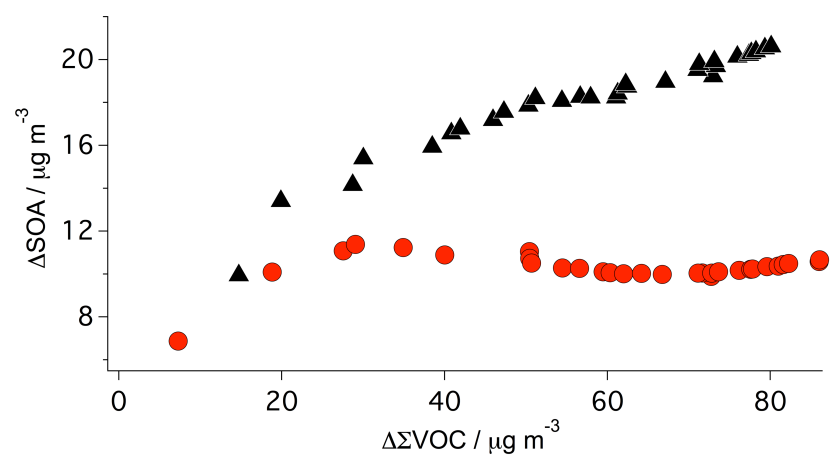

Figure 10. Time-dependent growth curves for two typical Betula pendula experiments: the nucleation experiment on 6 July 2009 (red circles) and the ammonium sulfate-seeded experiment on 7 July 2009 (black triangles), showing SOA growth behaviour with respect to consumption of the VOC precursors.

terpinene, SOA yields of $9-34 \%, 6-43(15) \%, 2-38 \%$ and $8-25 \%$, respectively, and for $\beta$-caryophyllene, $37-79(50) \%$ have been reported (Lee at al., 2006a and references therein; Alfarra at al., 2012). In a comparable study to ours, Mentel et al. (2009) reported a fractional mass yield of $11 \%$ for their Betula pendula experiments, slightly lower than those given here, but within the bounds of quantified experimental errors. The yield values obtained here for the Betula pendula mesocosm system lie roughly in the middle of the single-precursor yield range.

As can be seen from Fig. 3, the transfer of mass through the Betula pendula experiment appeared roughly conservative, with a small and steady loss of measured mass from the reaction matrix after $\sim 220 \mathrm{~min}$. With the addition of oxygen to the starting body of hydrocarbon material during such an experiment, the total measured mass (i.e. $\Sigma$ VOCs + SOA) within the system would be expected to increase with time. The absence of such a total measured mass gain (and indeed the mass deficit observed towards the end of the experiment) can most likely be accounted for by considering the various measurement uncertainties involved in producing these data (e.g. assumptions in PTR sensitivity, uncharacterised fragmentation following ionisation, instrument detection limits) and influences imposed by the chamber walls (including potential loss of more highly oxidised material from the gas phase and greater than expected loss of SOA). Indeed, there is potential for a system mass increase by the end of the experiment to lie within the uncertainty bounds of the CIRToF-MS and PTR-MS measurements alone; for example the average single-compound PTR measurement uncertainty is $\sim \pm 30 \%$, allowing the final measured value of $130 \mu \mathrm{g} \mathrm{m}^{-3}$ to have an upper limit of $170 \mu \mathrm{g} \mathrm{m}^{-3}$, greater than the starting value. Considering these results it seems that the system studied is reasonably well characterised, given the complications involved in such a task. 


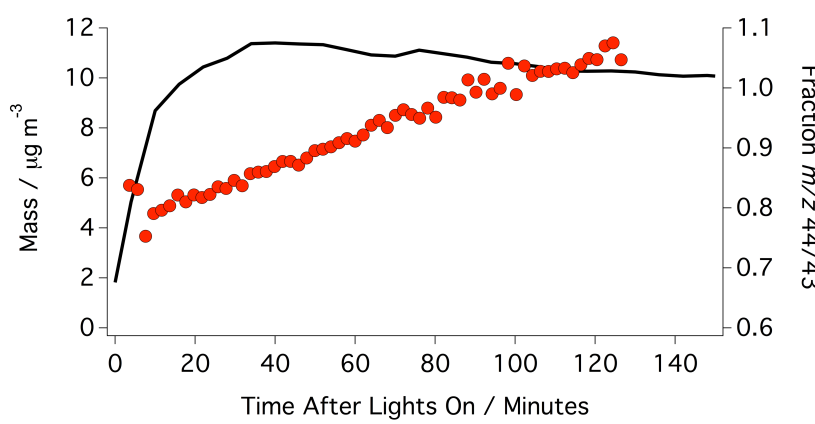

Figure 11. Temporal evolution of the $m / z$ 44/43 ratio (red circles) and wall loss-corrected SOA mass (black line) during a typical $\mathrm{Be}$ tula pendula experiment (6 July 2009), demonstrating the increase in oxygenated content of the SOA as the air matrix begins to age.

Certain insights into the mechanisms of SOA formation and growth during the Betula pendula experiments can be obtained through a combined examination of the VOC data, the time-dependent growth curves (Fig. 10) and the aerosol composition data. The data in Fig. 10 demonstrates that during oxidation of the Betula pendula emissions and in absence of a seed, SOA mass evolution can be roughly split into two phases. In the early stages of the experiment after nucleation, SOA mass growth increased somewhat rapidly with respect to the amount of precursors reacted; however, after roughly $30 \%$ of the initial precursor mass had been consumed, the rate of mass growth with respect to VOC precursor consumption was observed to reach an approximate steady state. When ammonium sulfate seed was present within the chamber, there was a similarly rapid initial growth with respect to VOC consumption; in this case, however, subsequent aerosol evolution was characterised by a roughly linear mass increase to a much higher final mass by the end of the experiment. Considering the various species of precursor VOCs detected in the Betula pendula plant chamber air, and the relative lifetimes of these VOCs, it would seem possible that initially the shorter-lived sesquiterpenes react to form a significant proportion of the high-mass, nucleating/condensing species, before being removed from the system (e.g. Jenkin et al., 2012). Subsequent aerosol mass formation, as the air in the reaction chamber ages towards the central phase of the experiment, is then likely to result from the partitioning of relatively more volatile products formed from slower-reacting monoterpenes, such as pinic and pinonic acid formed from $\alpha$ pinene oxidation (e.g. Jenkin, 2004; Camredon et al., 2010), and potentially products such as the primary acyclic unsaturated aldehydes, $(\mathrm{m} / z 111+93$; and products thereof $)$; the temporal profile of which demonstrates gas-phase loss concomitant with wall loss-corrected aerosol growth reaching a steady state.

Further understanding of the composition and evolution of SOA typical of temperate plant environs comes from investigation of Fig. 11, which shows the evolution of the fraction

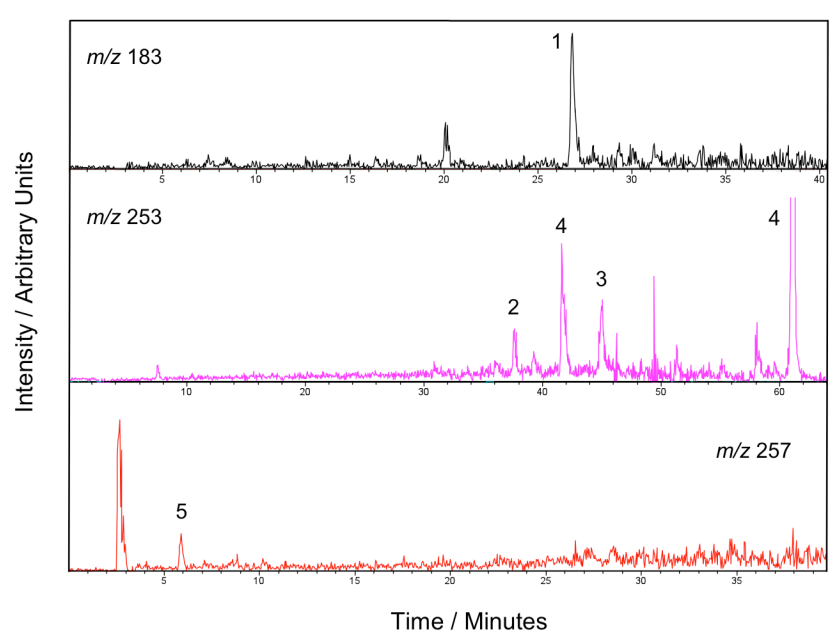

Figure 12. $\mathrm{LC}^{-M S^{2}}$ selected ion chromatograms derived from the off-line analysis of SOA collected on filters at the conclusion of a typical Betula pendula experiment (7 July 2009). Upper: $m / z \quad 183=$ molecular weight $(\mathrm{MW}) 184,1=c i s$-pinonic acid; middle: $m / z$ 253 $=$ MW 254, $2=\beta$-nocaryophyllonic acid, $3=\beta$-caryophyllinic acid, $4=$ similar to sesquiterpene SOA; lower: $m / z 257=\mathrm{MW} 118[2 \cdot[\mathrm{M}-\mathrm{H}]+\mathrm{Na}]^{-}$, also seen in myrcene SOA, with same $\mathrm{MS}^{2}$ spectra.

of the ratio of more/less oxygenated material present in the aerosol during the initial stages of a typical unseeded $\mathrm{Be}$ tula pendula experiment (6 July 2009). Figure 11 was constructed using the ratio of $\mathrm{m} / \mathrm{z} 44$ to 43 obtained from the AMS (i.e. $f 44 / 43$, where $m / z 44$ is derived from "more" oxidised material and $m / z 43$ from "less" oxidised material, $\mathrm{Ng}$ et al., 2010). In this instance, the $f 44 / 43$ ratio exhibits linear growth with time, from a value of $\sim 0.8$ to $\sim 1.1$, suggesting an increase in the oxygenated content of the aerosol as the experiment ages. Such an increase in oxygenated content is generally observed when precursor species contain multiple $\mathrm{C}=\mathrm{C}$ bonds (e.g. ocimene and myrcene), offering significant potential for higher aerosol $\mathrm{O}: \mathrm{C}$ composition (e.g. perhaps, species such as acyclic unsaturated aldehydes and their subsequent generations of products). Indeed, the evolution of the $f 44 / 43$ ratio observed here is consistent with those results obtained from single-precursor experiments investigating the acyclic monoterpene, myrcene and the sesquiterpene, $\beta$-caryophyllene (Alfarra et al., 2012, 2013).

Off-line compositional analysis of the SOA collected at the end of the Betula pendula experiments supports the findings obtained from the on-line gas-phase and bulk aerosol composition data. The LC-MS ${ }^{2}$ analysis produced chromatograms with peaks matching those seen in comparable single precursor BVOC experiments, with tracer compounds of both sesquiterpene and monoterpene SOA detected (Fig. 12). Amongst the compounds observed were those of molecular weight (MW) 238, 242, 254 and 256, corresponding to 3-[2,2-dimethyl-4-(1-methylene-4-oxo-butyl)- 
Table 3. Yields of isoprene oxidation products compared to literature values. Yields are an average from all Ficus experiments (seeded and unseeded) $(n=4)$ calculated at $4 \mathrm{~h}$ after lights on (HALO). Yield is based on the calculated relationship between the amount of isoprene reacted and the oxidation product in question.

\begin{tabular}{cccccl}
\hline Isoprene & IEPOX + ISOPOOH & MVK + MACR & Hydroxyacetone & Formaldehyde & Source \\
\hline 1 & 0.33 & 0.26 & 0.07 & & Williams et al. (1999) \\
1 & 0.05 & 0.36 & 0.05 & & Williams et al. (2001)* \\
1 & & 0.33 & & 0.67 & Zang et al. (2002) \\
1 & & $0.46-0.60$ & & $0.86-0.96$ & Niki et al. (1983) \\
& & & & Kamens et al. (1982) \\
1 & 0.18 & 0.25 & & & Surratt et al. (2010)*** \\
1 & & 0.27 & & & Kleindienst et al. (2009) \\
1 & $0.01-0.03$ & $0.17-0.36$ & $0-0.02$ & $0.02-0.07$ & This study \\
\hline
\end{tabular}

* $\mathrm{NO}_{\mathrm{x}}$ present;

** $\mathrm{NO}_{\mathrm{x}}$ absent.

cyclobutyl]-propionic acid, 3-hydroxy-3-[4-(3-hydroxy-1methylene-propyl)-2,2-dimethylcyclobutyl]-propionic acid, $\beta$-nocaryophyllonic acid/ $\beta$-caryophyllinic acid and 4-(2-(2carboxyethyl)-3,3-dimethylcyclobutyl)-4-oxobutanoic acid, respectively, produced during $\beta$-caryophyllene oxidation (e.g. Alfarra et al., 2012), and MW 184, corresponding to cis-pinonic acid, produced during $\alpha$-pinene oxidation. Many other terpene oxidation tracers were detected, including compounds of molecular weight 118 and 200, which are also prevalent in SOA obtained from single precursor myrcene experiments. This observation is in line with findings obtained from the gas-phase data, which suggest a relatively significant presence of gaseous acyclic unsaturated aldehydes that would originate from acyclic unsaturated terpenes, such as myrcene.

\subsection{Tropical species}

In addition to Betula pendula, we studied three tropical plant species: two figs (Ficus benjamina and Ficus cyathistipula) and one palm (Caryota millis); in this paper, we focus on results obtained from the fig plants. All three tropical species were found to be strong isoprene emitters, with very much smaller emissions of monoterpenes, sesquiterpenes and oxygenated VOCs (Table 2, Fig. 6).

During the tropical plant experiments, the primary gasphase isoprene oxidation products MACR, MVK, formaldehyde, isoprene hydroxy hydroperoxides and the secondary product hydroxyacetone were all observed (e.g. Figs. 5 and 6 and Tables S4 and S5 in the Supplement). MACR, isoprene epoxide (IEPOX), and isoprene hydroperoxide (ISOPOOH) and hydroxyacetone are all believed to be precursors to SOA formation (Jaoui et al., 2010; Carlton et al., 2009; Kleindienst et al., 2007, 2009; Paulot et al., 2009; Lee et al., 2006a, b; Kroll et al., 2006; Surratt et al., 2006; Claeys et al., 2004b; Rollins et al., 2009; Robinson et al., 2010). In this study, with the exception of MACR and MVK, these products all formed at yields lower than those previously reported (Ta- ble 3), with MACR + MVK, IEPOX + ISOPOOH, hydroxy acetone and formaldehyde being observed to form in yields of $17-36 \%, 1-3 \%, 0-2 \%$ and $2-7 \%$, respectively during our work. This disagreement may result from differences in $\mathrm{OH}$ concentrations and $\mathrm{NO}_{\mathrm{x}}$ concentrations in each of the experimental studies. Other isoprene products tentatively identified from the CIR-ToF-MS and PTR-MS data include C5alkene diols, C4-hydroxycarbonyls/methacrylic acid and 3methyl furan (Table S4 in the Supplement), which have also previously been associated with SOA formation (e.g. Claeys et al., 2004a, b; Surratt et al., 2006; Robinson et al., 2010). For a typical Ficus benjamina experiment (23 June 2009) the sum of these and other potential isoprene products, excluding MACR + MVK, was estimated to have a combined gasphase yield of the order of $18 \%$ (Fig. 5).

As can be seen in Fig. 6 mass transfer through the Ficus benjamina system was characterised by a slight mass decrease just after the start of the experiment followed by a gradual increase in mass with time. As stated in Sect. 4.1, a mass increase over time is expected during such an experiment, owing to the addition of oxygen to the precursor hydrocarbon material. Consequently, when considering the data presented in Fig. 6 in the context of potential uncertainties involved (including difficult-to-characterise influences imposed by the chamber walls), it appears that the system being studied is reasonably well characterised.

By comparing Figs. 3 and 6 we see that the monoterpenedominated Betula pendula system, which produces larger, lower-vapour pressure oxidation products than the isoprene dominated Ficus system, as well as measurable SOA, is the case which exhibits measured mass loss. From this comparison it is reasonable to assume a significant fraction of any mass deficit observed during Betula pendula oxidation could result from the loss of the heavier, lower-volatility compounds that are present in the Betula pendula oxidation system but not in the Ficus system.

Despite the detection of a number of first- and secondgeneration gas-phase products that have previously been di- 
rectly linked with isoprene SOA composition (Claeys et al., 2004a, b; Wang et al., 2004; Edney et al., 2005; Surratt et al., 2006; Healy et al., 2008), there was no accompanying evidence of SOA formation from the isoprene-emitting tropical plants during unseeded, nucleation-style experiments (Fig. 7). A lack of SOA mass formation during our unseeded Ficus benjamina experiments could have resulted from a number of different factors, not least of which was simply the absence of a seed surface (acidic or otherwise) to help facilitate partitioning of the semivolatile oxidation products to the aerosol phase and produce particles of sufficient size to have measurable particle mass (e.g. Kroll et al., 2006; P. Lin et al., 2012). Another potentially significant contributing factor in suppressing SOA formation during these experiments was the relatively low VOC / $\mathrm{NO}_{\mathrm{x}}$ ratio and the resultant gasphase chemistry. In the presence of high (in terms of ppbV level) $\mathrm{NO}_{\mathrm{x}}$ mixing ratios, $\mathrm{RO}_{2}$ radicals react with $\mathrm{NO}$ to produce mainly alkoxy (RO) radicals. For low-molecular mass VOCs such as isoprene, these RO radicals generally fragment into smaller, more volatile products that do not easily partition from the gas phase to the aerosol phase, resulting in a low SOA yield (Surratt et al., 2010). Conversely, under low $\mathrm{NO}_{\mathrm{x}}$ conditions, $\mathrm{RO}_{2}$ radicals are known to undergo self- and cross-reactions to produce organic peroxides and hydroperoxides of relatively low volatility. For example, Surratt et al. (2010) showed that under high $\mathrm{NO}_{\mathrm{x}}$ conditions the yield of the potentially SOA-forming gas-phase IEPOX was reduced with respect to the equivalent value under low $\mathrm{NO}_{\mathrm{x}}$ conditions, where IEPOX formed in substantial yields (upward of $75 \%$ ) from the further oxidation of ISOPOOH by $\mathrm{OH}$.

In contrast to our unseeded Ficus experiments, when an ammonium sulfate seed was present (and following wall loss correction), SOA mass was observed to form and evolve within the reaction chamber (Fig. 9). From estimates of the total concentrations of precursor VOCs within the reaction chamber matrix (primarily isoprene, see e.g. Fig. 5), an SOA mass yield of the order of $10-14 \%$ was obtained for the $\mathrm{Fi}$ cus cyathistipula system. If it were to be assumed that the SOA were solely formed from oxidation products of isoprene, as the major emitted VOC, this yield would appear excessive in comparison with those obtained previously from single-precursor isoprene studies, $\sim 0.1-5.5 \%$ (van Donkelaar et al., 2007; Kleindienst et al., 2009, 2007; Kroll et al., 2005, 2006; Claeys et al., 2004a; Edney et al., 2005; van Brégonzio-Rozier et al., 2014). However, we must consider that the mesocosm system is in fact an ensemble of precursors, albeit an ensemble dominated by isoprene, analogous to ambient air above a tropical forested region (Hewitt et al., 2010; MacKenzie et al., 2011).

For the experiments of 30 June 2009 and 2 July 2009, for which SOA yields were obtained for the Ficus cyathistipula system, a fraction of camphor was also observed in the air entering the reaction chamber (presumably, for these two particular experiments, sesquiterpenes and monoterpenes were present at concentrations below the detection limits of the PTR-MS and CIR-ToF-MS). The concentration of camphor at lights on was estimated to be $\sim 0.5-0.9 \mathrm{ppbV}$ for the $\mathrm{Fi}^{-}$cus cyathistipula system and $\sim 1.4-2.7 \mathrm{ppbV}$ for Ficus benjamina, and the sum of all nonprecursor ions in the CIRToF mass spectrum $m / z>100$ (mostly indicative of nonisoprene-like oxidation products; excluding $\mathrm{m} / \mathrm{z} 103$ and 117) was estimated to be of the order of $2 \mathrm{ppbV}$ by the end of the experiments. This calculation approximates the $m / z>100$ summation as one large, multifunctional analyte with a PTR sensitivity similar to pinonaldehyde (a typical multifunctional, relatively high-MW molecule resulting from terpene oxidation). Continuing this assumption and taking a range of known VOC terpene product yields $\left(Y_{\mathrm{VOC}}^{P}\right)$ obtained from previous work at the Manchester chamber $\left(Y_{\mathrm{VOC}}^{\mathrm{P}}=100 \%\right.$ the limiting case, $77 \%$ from Ficus benjamina oxidation, $55 \%$ from Betula pendula oxidation, and $29 \%$ for pinonaldehyde and $\left.\Sigma\left(I_{111}, I_{93}\right)\right)$, a non-isoprene $\mathrm{VOC}_{\text {precursor }}$ concentration may be estimated. Taking a range of known SOA yields obtained from the same reaction chamber (i.e. $\alpha$-pinene, myrcene, linalool and $\beta$-caryophyllene; Alfarra et al., 2013), the SOA yield obtained here for the Betula pendula system and the estimate of $\left[\mathrm{VOC}_{\text {precursor }}\right]$, Eq. (2) may be solved to provide a crude estimate of the mass of SOA formed from non-isoprene precursors. Consequently, an estimate of the residual SOA mass derived from isoprene oxidation within the Ficus system can be inferred for each of the experiments shown in Fig. 9.

For 78 of the 120 measurement-and parameter sets tested, the estimated residual SOA mass resulting solely from isoprene oxidation was negative - that is, production of SOA from isoprene oxidation was not required to close the mass balance. Values were calculated based on the widest range of peak masses observed during the Ficus experiments $\left(M_{\mathrm{p}}=1.3 \mu \mathrm{g} \mathrm{\textrm {m } ^ { - 3 }}\right.$ and $\left.5.5 \mu \mathrm{g} \mathrm{m}^{-3}\right)$, and assume the lowest $(29 \%)$ and highest $(100 \%)$ VOC terpene yields and lowest $(5 \%)$ and highest (47\%) SOA yields from non-isoprene precursors, respectively, as observed in previous experiments conducted within this chamber. These ranges result in calculated residual SOA mass of -28.5 to $+5.0 \mu \mathrm{g} \mathrm{m}^{-3}$ produced solely from isoprene oxidation. Hence, there are combinations of measurements, observations and oxidation/phasechange parameters - omitting isoprene and its oxidation products - that can account for $\sim 20$ times the observed aerosol mass production, and other combinations of measurements and parameters that leave up to $\sim 90 \%$ of the condensed mass to be explained by isoprene oxidation. If, instead of using the limiting cases, the closest approximation to the Ficus cyathistipula system is used (i.e. $Y_{\mathrm{VOC}}=77 \%$ and $Y_{\mathrm{SOA}}=Y_{a-\text { pinene }}=15 \%$ ), non-isoprene products could have accounted for around $145 \%$ of the SOA mass that was produced. We have no way of assigning formal likelihoods to each set of measurements and parameters in this exercise, but we note that the great preponderance of parameter combinations (78 out of 120 measurement and parameter sets tested) 
do not require an isoprene contribution to the SOA mass under our experimental conditions. Moreover, our experiments produced much less SOA mass than would be expected from published experiments using individual mono- and sesquiterpenes.

There are three principal reasons why the estimates of aerosol production from isoprene in the tropical plant experiments span such a large range. Firstly, the plants in the mesocosm emit a complicated mixture of biogenic VOCs, some of which are known to oxidise much more rapidly than isoprene and will produce condensable compounds when oxidised. Secondly, these minor compounds co-emitted from principally isoprene-emitting tropical trees are imperfectly quantified because of the sensitivity of the chemical ionisation (PTR and CIR) instruments. Thirdly, these minor co-emissions are imperfectly characterised because many higher-MW compounds, such as the mono- and sesquiterpenes, are isobaric in the PTR and CIR instruments and so precise chemical structures cannot easily be assigned. Without better instrument detection sensitivity and high timeresolution chemical identification for the reactive compounds co-emitted with isoprene, it is not possible to constrain the aerosol yield from the tropical plants any further. Unfortunately, insufficient SOA mass formed during Ficus experiments to allow us to conduct any form of compositional analysis.

\subsection{Atmospheric significance}

Our results are specific to $\mathrm{VOC} / \mathrm{NO}_{\mathrm{x}}$ ratios of 3-9 and $\mathrm{NO}_{\mathrm{x}}$ mixing ratios of $\sim 2 \mathrm{ppbV}$. Note, however, that the three reasons given above for the uncertainty in the aerosol production ascribed to isoprene in our experiments, will also pertain to field measurements, often being exacerbated by variability and the difficulties of operating in the field. A contribution of isoprene to SOA is supported by recent observations of isoprene-related SOA formation above the tropical forest of Danum Valley, Borneo, a high-isoprene, low- $\mathrm{NO}_{\mathrm{x}}$ region (typical isoprene $/ \mathrm{NO}_{\mathrm{x}}$ ratio of $20: 1$ ) (Hewitt et al., 2010). Robinson et al. (2010) observed that up to $15 \%$ by mass of atmospheric submicron organic aerosol above the tropical forest of Danum Valley was comprised of methyl furan, the most likely source of which is the oxidation of isoprene (i.e. thermal decomposition of isoprene-derived SOA) (Ruppert and Becker, 2000; Robinson et al., 2010; P. Lin et al., 2012; Budisulistiorini et al., 2013). Although much smaller in magnitude, the monoterpene emissions measured at Danum Valley were more than adequate to account for the remaining submicron organic aerosol (MacKenzie et al., 2011), just as in the majority of aerosol mass calculations for principally isoprene-emitting tropical trees, described above.

It has recently been proposed that isoprene can inhibit aerosol formation when present in air containing other potential SOA precursors, such as mono- and sesquiterpenes (Kiendler-Scharr et al., 2009a). Kiendler-Scharr et al. pro- pose that isoprene could effectively act as an $\mathrm{OH}$ scavenger, suppressing new particle formation by slowing the oxidation of available monoterpenes (and presumably sesquiterpenes). In line with this thesis, interpretation of the results obtained from our seeded experiments with Ficus species leaves room for a potential role for isoprene in inhibiting SOA formation under certain atmospheric conditions; that is, our results imply that isoprene may have a negative impact on the overall SOA-forming potential of air containing other biogenic SOA precursors. However, owing to the constraints laid upon our experiments by the instrumentation and apparatus employed, it is difficult to assign a given certainty level to the role played by isoprene in the ambient atmosphere, and caution should be taken when interpreting such findings.

The fact that isoprene accounts for approximately $50 \%$ of the total global burden of non-methane VOC (Guenther et al., 2006) would make it a significant contributor to global SOA. It has been estimated that, even if the SOA yield from isoprene is small (e.g. $1 \%$ ), the overall contribution to total atmospheric aerosol could be up to $6 \mathrm{Tg} \mathrm{yr}^{-1}$ (Carlton et al., 2009). Van Donkelaar et al. (2007) found that using an isoprene SOA yield of $2 \%$ improved the relationship between model simulations and organic aerosol measurements, contributing $10-50 \%$ of the total organic aerosol loading over the United States during the summer. Understanding the exact role played by isoprene in air containing many different VOCs, and being able to account for the differing isoprene SOA yields under contrasting $\mathrm{NO}_{\mathrm{x}}$ and acidity (P. Lin et al., 2012; Y. H. Lin et al., 2012; Pye et al., 2013) environments, will undoubtedly help to bring significant further improvements to global modelling estimates of total SOA loading (Couvidat and Seigneur, 2011).

Further to any such potential impacts imposed by isoprene, it has been shown that a range of other BVOC emissions, released in response to a range of environmental stress factors, can also have significant impacts on biogenic SOA formation and yield (Mentel et al., 2009). It has been shown that the emissions of sesquiterpenes, methyl salicylate and $\mathrm{C}_{17}$ BVOCs, released as a result of certain environmental stress factors have a net positive impact on SOA yield; whereas certain stress-induced green-leaf volatiles ( $(Z)-3$-hexenol and (Z)-3-hexenylacetate) behave similarly to isoprene, suppressing SOA formation (Mentel et al., 2009).

Given the highly differing reported yields of isoprene SOA under various oxidant schemes, the uncertainty in the exact role played by isoprene and its oxidation products in realistic mixtures of VOCs (in particular in the context of SOA nucleation rates; Kiendler-Scharr et al., 2009a) and the lack of knowledge regarding stress induced BVOCs, their atmospheric oxidation and their roles in biogenic SOA formation (and impact on chemical and physical properties), we suggest that there is a pressing requirement for additional, atmosphere-relevant laboratory and field studies to provide the necessary insight for successful control of biogenic SOA (Carlton et al., 2010). 


\section{The Supplement related to this article is available online at doi:10.5194/acp-14-12781-2014-supplement.}

Acknowledgements. The authors gratefully acknowledge the UK Natural Environment Research Council (NERC) for funding of the APPRAISE ACES (NE/E011217/1), ACIDPRUF (NE/I020121/1) and CLAIRE-UK (NE/I012567/1) consortia. The authors would also like to acknowledge support from the EU-FP7 EUROCHAMP2 project. M. R. Alfarra was supported by the UK National Centre for Atmospheric Sciences (NCAS) funding. The authors would like to thank Iain White for his assistance with VOC measurements and instrument calibration. This is paper number 1 from the Birmingham Institute of Forest Research.

Edited by: K. Tsigaridis

\section{References}

Alfarra, M. R., Paulsen, D., Gysel, M., Garforth, A. A., Dommen, J., Prévôt, A. S. H., Worsnop, D. R., Baltensperger, U., and Coe, H.: A mass spectrometric study of secondary organic aerosols formed from the photooxidation of anthropogenic and biogenic precursors in a reaction chamber, Atmos. Chem. Phys., 6, 52795293, doi:10.5194/acp-6-5279-2006, 2006.

Alfarra, M. R., Hamilton, J. F., Wyche, K. P., Good, N., Ward, M. W., Carr, T., Barley, M. H., Monks, P. S., Jenkin, M. E., Lewis, A. C., and McFiggans, G. B.: The effect of photochemical ageing and initial precursor concentration on the composition and hygroscopic properties of $\beta$-caryophyllene secondary organic aerosol, Atmos. Chem. Phys., 12, 6417-6436, doi:10.5194/acp12-6417-2012, 2012.

Alfarra, M. R., Good, N., Wyche, K. P., Hamilton, J. F., Monks, P. S., Lewis, A. C., and McFiggans, G.: Water uptake is independent of the inferred composition of secondary aerosols derived from multiple biogenic VOCs, Atmos. Chem. Phys., 13, 1176911789, doi:10.5194/acp-13-11769-2013, 2013.

Bahreini, R., Keywood, M. D., Ng, N. L., Varutbangkul, V., Gao, S., Flagan, R. C., Seinfeld, J. H., Worsnop, D. R., and Jimenez, J. L.: Measurements of secondary organic aerosol from oxidation of cycloalkenes, terpenes, and m-xylene using an Aerodyne aerosol mass spectrometer, Environ. Sci. Technol., 39, 5674-5688, 2005.

Baltensperger, U., Dommen, J., Alfarra, R., Duplissy, J., Gaeggeler, K., Metzger, A., Facchini, M. C., Decesari, S., Finessi, E., Reinnig, C., Schott, M., Warnke, J., Hoffmann, T., Klatzer, B., Puxbaum, H., Geiser, M., Savi, M., Lang, D., Kalberer, M., and Geiser, T.: Combined determination of the chemical composition and of health effects of secondary organic aerosols: The POLYSOA project, J. Aerosol Med. Pulm. Drug Deliv., 21, 145154, 2008.

Blake, R. S., Whyte, C., Hughes, C. O., Ellis, A. M., and Monks, P. S.: Demonstration of Proton-Transfer Reaction Time-of-Flight Mass Spectrometry form Real-Time Analysis of Trace Volatile Organic Compounds, Analyt. Chem., 76, 3841-3845, 2003.

Blake, R. S., Monks, P. S., and Ellis, A. M.: Proton Transfer Reaction Mass Spectrometry, Chem. Rev., 109, 861-896, 2009.
Brégonzio-Rozier, L., Siekmann, F., Giorio, C., Pangui, E., Morales, S. B., Temime-Roussel, B., Gratien, A., Michoud, V., Ravier, S., Tapparo, A., Monod, A., and Doussin, J.-F.: Gaseous products and Secondary Organic Aerosol formation during long term oxidation of isoprene and methacrolein, Atmos. Chem. Phys. Discuss., 14, 22507-22545, doi:10.5194/acpd-14-225072014, 2014.

Budisulistiorini, S. H., Canagaratna, M. R., Croteau, P. L., Marth, W. J., Baumann, K., Edgerton, E. S., Shaw, S. L., Knipping, E. M., Worsnop, D. R., Jayne, J. T., Gold, A., and Surratt, J. D.: Real-Time Continuous Characterization of Secondary Organic Aerosol Derived from Isoprene Epoxydiols in Downtown Atlanta, Georgia, Using the Aerodyne Aerosol Chemical Speciation Monitor, Environ. Sci. Technol., 47, 686-694, doi:10.1021/es400023n, 2013.

Canagaratna, M. R., Jayne, J. T., Jimenez, J. L., Allan, J. D., Alfarra, M. R., Zhang, Q., Onasch, T. B., Drewnick, F., Coe, H., Middlebrook, A., Delia, A., Williams, L. R., Trimborn, A. M., Northway, M. J., DeCarlo, P. F., Kolb, C. E., Davidovits, P., and Worsnop, D. R.: Chemical and microphysical characterization of ambient aerosols with the aerodyne aerosol mass spectrometer, Mass Spectrom. Rev., 26, 185-222, 2007.

Carlton, A. G., Wiedinmyer, C., and Kroll, J. H.: A review of Secondary Organic Aerosol (SOA) formation from isoprene, Atmos. Chem. Phys., 9, 4987-5005, doi:10.5194/acp-9-4987-2009, 2009.

Carlton, A. G., Pinder, R. W., Bhave, P. V., and Pouliot, G. A.: To What Extent Can Biogenic SOA be Controlled?, Environ. Sci. Technol., 44, 3376-3380, 2010.

Carslaw, K. S., Boucher, O., Spracklen, D. V., Mann, G. W., Rae, J. G. L., Woodward, S., and Kulmala, M.: A review of natural aerosol interactions and feedbacks within the Earth system, Atmos. Chem. Phys., 10, 1701-1737, doi:10.5194/acp-10-17012010, 2010.

Carvalho, L. R. F., Vasconcellos, P. C., Mantovani, W., Pool, C. S., and Pisani, S. O.: Measurements of biogenic hydrocarbons and carbonyl compounds emitted by trees from temperate warm Atlantic rainforest, Brazil, J. Environ. Monit., 7, 493-499, 2005.

Claeys, M., Graham, B., Vas, G., Wang, W., Vermeylen, R., Pashynska, V., Cafmeyer, J., Guyon, P., Andreae, M. O., Artaxo, P., and Maenhaut, W.: Formation of secondary organic aerosols through photooxidation of isoprene, Science, 303, 1173-1176, 2004a.

Claeys, M., Wang, W., Ion, A. C., Kourtchev, I., Gelencser, A., and Maenhaut, W.: Formation of secondary organic aerosols from isoprene and its gas-phase oxidation products through reaction with hydrogen peroxide, Atmos. Environ., 38, 4093-4098, 2004b.

Couvidat, F. and Seigneur, C.: Modeling secondary organic aerosol formation from isoprene oxidation under dry and humid conditions, Atmos. Chem. Phys., 11, 893-909, doi:10.5194/acp-11893-2011, 2011.

Dommen, J., Hellén, H., Saurer, M., Jaeggi, M., Siegwolf, R., Metzger, A., Duplissy, J., Fierz, M., and Baltensperger, U.: Determination of the Aerosol Yield of Isoprene in the Presence of an Organic Seed with Carbon Isotope Analysis, Environ. Sci. Technol., 43, 6697-6702, 2009.

Donahue, N. M., Robinson, A. L., and Pandis, S. N.: Atmospheric organic particulate matter: From smoke to secondary organic aerosol, Atmos. Environ., 43, 94-106, 2009. 
Drewnick, F., Hings, S. S., DeCarlo, P., Jayne, J. T., Gonin, M., Fuhrer, K., Weimer, S., Jimenez, J. L., Demerjian, K. L., Borrmann, S., and Worsnop, D. R.: A new time-of-flight aerosol mass spectrometer (TOF-AMS) - Instrument description and first field deployment, Aerosol Sci. Technol., 39, 637-658, 2005.

Edney, E. O., Kleindienst, T. E., Jaoui, M., Lewandowski, M., Offenberg, J. H., Wang, W., and Claeys, M.: Formation of 2-methyl tetrols and 2-methylglyceric acid in secondary organic aerosol from laboratory irradiated isoprene/NOX/SO2/air mixtures and their detection in ambient $\mathrm{PM}_{2.5}$ samples collected in the eastern United States, Atmos. Environ., 39, 5281-5289, 2005.

Geron, C., Owen, S., Guenther, A., Greenberg, J., Rasmussen, R., Hui Bai, J., Li, Q.-J., and Baker, B.: Volatile organic compounds from vegetation in southern Yunnan Province, China: Emission rates and some potential regional implications, Atmos. Environ., 40, 1759-1773, 2006.

Guenther, A., Karl, T., Harley, P., Wiedinmyer, C., Palmer, P. I., and Geron, C.: Estimates of global terrestrial isoprene emissions using MEGAN (Model of Emissions of Gases and Aerosols from Nature), Atmos. Chem. Phys., 6, 3181-3210, doi:10.5194/acp-63181-2006, 2006.

Guenther, A. B., Jiang, X., Heald, C. L., Sakulyanontvittaya, T., Duhl, T., Emmons, L. K., and Wang, X.: The Model of Emissions of Gases and Aerosols from Nature version 2.1 (MEGAN2.1): an extended and updated framework for modeling biogenic emissions, Geosci. Model Dev., 5, 1471-1492, doi:10.5194/gmd-51471-2012, 2012.

Gunthe, S. S., King, S. M., Rose, D., Chen, Q., Roldin, P., Farmer, D. K., Jimenez, J. L., Artaxo, P., Andreae, M. O., Martin, S. T., and Poschl, U.: Cloud condensation nuclei in pristine tropical rainforest air of Amazonia: size-resolved measurements and modeling of atmospheric aerosol composition and CCN activity, Atmos. Chem. Phys., 9, 7551-7575, doi:10.5194/acp-9-75512009, 2009.

Hallquist, M., Wenger, J. C., Baltensperger, U., Rudich, Y., Simpson, D., Claeys, M., Dommen, J., Donahue, N. M., George, C., Goldstein, A. H., Hamilton, J. F., Herrmann, H., Hoffmann, T., Iinuma, Y., Jang, M., Jenkin, M. E., Jimenez, J. L., KiendlerScharr, A., Maenhaut, W., McFiggans, G., Mentel, T. F., Monod, A., Prevot, A. S. H., Seinfeld, J. H., Surratt, J. D., Szmigielski, R., and Wildt, J.: The formation, properties and impact of secondary organic aerosol: current and emerging issues, Atmos. Chem. Phys., 9, 5155-5236, doi:10.5194/acp-9-5155-2009, 2009.

Hewitt, C. N., Lee, J. D., MacKenzie, A. R., Barkley, M. P., Carslaw, N., Carver, G. D., Chappell, N. A., Coe, H., Collier, C., Commane, R., Davies, F., Davison, B., Di Carlo, P., Di Marco, C. F., Dorsey, J. R., Edwards, P. M., Evans, M. J., Fowler, D., Furneaux, K. L., Gallagher, M., Guenther, A., Heard, D. E., Helfter, C., Hopkins, J., Ingham, T., Irwin, M., Jones, C., Karunaharan, A., Langford, B., Lewis, A. C., Lim, S. F., MacDonald, S. M., Mahajan, A. S., Malpass, S., McFiggans, G., Mills, G., Misztal, P., Moller, S., Monks, P. S., Nemitz, E., Nicolas-Perea, V., Oetjen, H., Oram, D. E., Palmer, P. I., Phillips, G. J., Pike, R., Plane, J. M. C., Pugh, T., Pyle, J. A., Reeves, C. E., Robinson, N. H., Stewart, D., Stone, D., Whalley, L. K., and Yin, X.: Overview: oxidant and particle photochemical processes above a south-east Asian tropical rainforest (the OP3 project): introduction, rationale, location characteristics and tools, Atmos. Chem. Phys., 10, 169-199, doi:10.5194/acp-10-169-2010, 2010.
IPCC: Climate change 2007: The Physical Science Basis, in, Cambridge University Press, Cambridge, 2007.

Isaksen, I. S. A., Granier, C., Myhre, G., Berntsen, T. K., Dalsoren, S. B., Gauss, M., Klimont, Z., Benestad, R., Bousquet, P., Collins, W., Cox, T., Eyring, V., Fowler, D., Fuzzi, S., Jockel, P., Laj, P., Lohmann, U., Maione, M., Monks, P., Prevot, A. S. H., Raes, F., Richter, A., Rognerud, B., Schulz, M., Shindell, D., Stevenson, D. S., Storelvmo, T., Wang, W. C., van Weele, M., Wild, M., and Wuebbles, D.: Atmospheric composition change: Climate-Chemistry interactions, Atmos. Environ. 43, 5138-5192, doi:10.1016/j.atmosenv.2009.08.003, 2009.

Jang, M. S., Czoschke, N. M., Lee, S., and Kamens, R. M.: Heterogeneous atmospheric aerosol production by acidcatalyzed particle-phase reactions, Science, 298, 814-817, doi:10.1126/science.1075798, 2002.

Jaoui, M., Corse, E. W., Lewandowski, M., Offenberg, J. H., Kleindienst, T. E., and Edney, E. O.: Formation of organic tracers for isoprene SOA under acidic conditions, Atmos. Environ., 44, 1798-1805, doi:10.1016/j.atmosenv.2010.01.018, 2010.

Jenkin, M. E., Saunders, S. M., and Pilling, M. J.: The tropospheric degradation of volatile organic compounds: a protocol for mechanism development, Atmos. Environ., 31, 81-104, 1997.

Jenkin, M. E.: Modelling the formation and composition of secondary organic aerosol from $\alpha$ - and $\beta$-pinene ozonolysis using MCM v3, Atmos. Chem. Phys., 4, 1741-1757, doi:10.5194/acp4-1741-2004, 2004.

Jenkin, M. E., Wyche, K. P., Evans, C. J., Carr, T., Monks, P. S., Alfarra, M. R., Barley, M. H., McFiggans, G. B., Young, J. C., and Rickard, A. R.: Development and chamber evaluation of the MCM v3.2 degradation scheme for $\beta$-caryophyllene, Atmos. Chem. Phys., 12, 5275-5308, doi:10.5194/acp-12-52752012, 2012.

Junkermann, W., Hacker, J., Lyons, T., and Nair, U.: Land use change suppresses precipitation, Atmos. Chem. Phys., 9, 65316539, doi:10.5194/acp-9-6531-2009, 2009.

Kanawade, V. P., Jobson, B. T., Guenther, A. B., Erupe, M. E., Pressley, S. N., Tripathi, S. N., and Lee, S. H.: Isoprene suppression of new particle formation in a mixed deciduous forest, Atmos. Chem. Phys., 11, 6013-6027, doi:10.5194/acp-11-60132011, 2011.

Karl, M., Tsigaridis, K., Vignati, E., and Dentener, F.: Formation of secondary organic aerosol from isoprene oxidation over Europe, Atmos. Chem. Phys., 9, 7003-7030, doi:10.5194/acp-97003-2009, 2009.

Kiendler-Scharr, A., Wildt, J., Dal Maso, M., Hohaus, T., Kleist, E., Mentel, T. F., Tillmann, R., Uerlings, R., Schurr, U., and Wahner, A.: New particle formation in forests inhibited by isoprene emissions, Nature, 461, 381-384, 2009a.

Kiendler-Scharr, A., Zhang, Q., Hohaus, T., Kleist, E., Mensah, A., Mentel, T. F., Spindler, C., Uerlings, R., Tillmann, R., and Wildt, J.: Aerosol Mass Spectrometric Features of Biogenic SOA: Observations from a Plant Chamber and in Rural Atmos. Environ.s, Environ. Sci. Technol., 43, 8166-8172, 2009b.

Kim, D. Y., and Ramanathan, V.: Solar radiation budget and radiative forcing due to aerosols and clouds, J. Geophys. Res.-Atmos., 113, D02203, doi:10.1029/2007JD008434, 2008.

Kleindienst, T. E., Edney, E. O., Lewandowski, M., Offenberg, J. H., and Jaoui, M.: Secondary organic carbon and aerosol yields from 
the irradiations of isoprene and alpha-pinene in the presence of $\mathrm{NO}_{\mathrm{X}}$ and $\mathrm{SO}_{2}$, Environ. Sci. Technol., 40, 3807-3812, 2006.

Kleindienst, T. E., Lewandowski, M., Offenberg, J. H., Jaoui, M., and Edney, E. O.: Ozone-isoprene reaction: Re-examination of the formation of secondary organic aerosol, Geophys. Res. Lett., 34, L01805, doi:10.1029/2006GL027485, 2007.

Kleindienst, T. E., Lewandowski, M., Offenberg, J. H., Jaoui, M., and Edney, E. O.: The formation of secondary organic aerosol from the isoprene plus $\mathrm{OH}$ reaction in the absence of $\mathrm{NO}_{\mathrm{x}}$, Atmos. Chem. Phys., 9, 6541-6558, doi:10.5194/acp-9-6541-2009, 2009.

Kroll, J. H., Ng, N. L., Murphy, S. M., Flagan, R. C., and Seinfeld, J. H.: Secondary organic aerosol formation from isoprene photooxidation under high- $\mathrm{NO}_{\mathrm{x}}$ conditions, Geophys. Res. Lett., 32, L18808, doi:10.1029/2005GL023637, 2005.

Kroll, J. H., Ng, N. L., Murphy, S. M., Flagan, R. C., and Seinfeld, J. H.: Secondary organic aerosol formation from isoprene photooxidation, Environ. Sci. Technol., 40, 1869-1877, doi:10.1021/es0524301, 2006.

Lee, A., Goldstein, A. H., Kroll, J. H., Ng, N. L., Varutbangkul, V., Flagan, R. C., and Seinfeld, J. H.: Gas-phase products and secondary aerosol yields from the photooxidation of 16 different terpenes, J. Geophys. Res.-Atmos., 111, D17305, doi:10.1029/2006jd007050, 2006a.

Lee, A., Goldstein, A. H., Keywood, M. D., Gao, S., Varutbangkul, V., Bahreini, R., Ng, N. L., Flagan, R. C., and Seinfeld, J. H.: Gas-phase products and secondary organic aerosol yields from the ozonolysis of ten different terpenes, J. Geophys. Res., 111, D07302, doi:10.1029/2006JD0070502006b.

Limbeck, A., Kulmala, M., and Puxbaum, H.: Secondary organic aerosol formation in the atmosphere via heterogeneous reaction of gaseous isoprene on acid particles, Geophy. Res. Lett., 30, 1996, doi:10.1029/2003GL017738, 2003.

Lin, P., Yu, J. Z., Engling, G., and Kalberer, M.: Organosulfates in Humic-like Substance Fraction Isolated from Aerosols at Seven Locations in East Asia: A Study by Ultra-High-Resolution Mass Spectrometry, Environ. Sci. Technol., 46, 13118-13127, doi:10.1021/es303570v, 2012.

Lin, Y. H., Zhang, Z., Docherty, K. S., Zhang, H., Budisulistiorini, S. H., Rubitschun, C. L., Shaw, S. L., Knipping, E. M., Edgerton, E. S., Kleindienst, T. E., Gold, A., and Surratt, J. D.: Isoprene Epoxydiols as Precursors to Secondary Organic Aerosol Formation: Acid-Catalyzed Reactive Uptake Studies with Authentic Compounds, Environ. Sci. Technol., 46, 250258, doi:10.1021/es202554c, 2012, 2012.

MacKenzie, A. R., Langford, B., Pugh, T. A. M., Robinson, N., Misztal, P. K., Heard, D. E., Lee, J. D., Lewis, A. C., Jones, C. E., Hopkins, J. R., Phillips, G., Monks, P. S., Karunaharan, A., Hornsby, K. E., Nicolas-Perea, V., Coe, H., Gabey, A. M., Gallagher, M. W., Whalley, L. K., Edwards, P. M., Evans, M. J., Stone, D., Ingham, T., Commane, R., Furneaux, K. L., McQuaid, J. B., Nemitz, E., Seng, Y. K., Fowler, D., Pyle, J. A., and Hewitt, C. N.: The atmospheric chemistry of trace gases and particulate matter emitted by different land uses in Borneo, Phil. Trans. Roy. Soc. B, 366, 3177-3195, 10.1098/rstb.2011.0053, 2011.

Mentel, T. F., Wildt, J., Kiendler-Scharr, A., Kleist, E., Tillmann, R., Dal Maso, M., Fisseha, R., Hohaus, T., Spahn, H., Uerlings, R., Wegener, R., Griffiths, P. T., Dinar, E., Rudich, Y., and Wahner, A.: Photochemical production of aerosols from real plant emis- sions, Atmos. Chem. Phys., 9, 4387-4406, doi:10.5194/acp-94387-2009, 2009.

Mercado, L. M., Bellouin, N., Sitch, S., Boucher, O., Huntingford, C., Wild, M., and Cox, P. M.: Impact of changes in diffuse radiation on the global land carbon sink, Nature, 458, 1014-1087, 2009.

Meyer, N. K., Duplissy, J., Gysel, M., Metzger, A., Dommen, J., Weingartner, E., Alfarra, M. R., Prevot, A. S. H., Fletcher, C., Good, N., McFiggans, G., Jonsson, A. M., Hallquist, M., Baltensperger, U., and Ristovski, Z. D.: Analysis of the hygroscopic and volatile properties of ammonium sulphate seeded and unseeded SOA particles, Atmos. Chem. Phys., 9, 721-732, doi:10.5194/acp-9-721-2009, 2009.

Ng, N. L., Kroll, J. H., Keywood, M. D., Bahreini, R., Varutbangkul, V., Flagan, R. C., Seinfeld, J. H., Lee, A., and Goldstein, A. H.: Contribution of first- versus second-generation products to secondary organic aerosols formed in the oxidation of biogenic hydrocarbons, Environ. Sci. Technol., 40, 2283-2297, 2006.

Nguyen, T. B., Coggon, M. M., Bates, K. H., Zhang, X., Schwantes, R. H., Schilling, K. A., Loza, C. L., Flagan, R. C., Wennberg, P. O., and Seinfeld, J. H.: Organic aerosol formation from the reactive uptake of isoprene epoxydiols (IEPOX) onto nonacidified inorganic seeds, Atmos. Chem. Phys., 14, 3497-3510, doi:10.5194/acp-14-3497-2014, 2014.

Paulot, F., Crounse, J. D., Kjaergaard, H. G., Kurten, A., St Clair, J. M., Seinfeld, J. H., and Wennberg, P. O.: Unexpected Epoxide Formation in the Gas-Phase Photooxidation of Isoprene, Science, 325, 730-733, 2009.

Pye, H. O. T., Pinder, R. W., Piletic, I. R., Xie, Y., Capps, S. L., Lin, Y. H., Surratt, J. D., Zhang, Z., Gold, A., Luecken, D. J., Hutzell, W. T., Jaoui, J., Offenberg, J. H., Kleindienst, T. E., Lewandowski, M., and Edney, E. O.: Epoxide Pathways Improve Model Predictions of Isoprene Markers and Reveal Key Role of Acidity in Aerosol Formation, Environ. Sci. Technol., 47, 11056-11064, doi:10.1021/es402106h, 2013.

Riipinen, I., Yli-Juuti, T., Pierce, J. R., Petaja, T., Worsnop, D. R., Kulmala, M., and Donahue, N. M.: The contribution of organics to atmospheric nanoparticle growth, Nature Geosci, 5, 453-458, 2012.

Robinson, N. H., Hamilton, J. F., Allan, J. D., Langford, B., Oram, D. E., Chen, Q., Docherty, K., Farmer, D. K., Jimenez, J. L., Ward, M. W., Hewitt, C. N., Barley, M. H., Jenkin, M. E., Rickard, A. R., Martin, S. T., McFiggans, G., and Coe, H.: Evidence for a significant proportion of Secondary Organic Aerosol from isoprene above a maritime tropical forest, Atmos. Chem. Phys., 11, 1039-1050, doi:10.5194/acp-11-1039-2011, 2011.

Rollins, A. W., Kiendler-Scharr, A., Fry, J. L., Brauers, T., Brown, S. S., Dorn, H. P., Dube, W. P., Fuchs, H., Mensah, A., Mentel, T. F., Rohrer, F., Tillmann, R., Wegener, R., Wooldridge, P. J., and Cohen, R. C.: Isoprene oxidation by nitrate radical: alkyl nitrate and secondary organic aerosol yields, Atmos. Chem. Phys., 9, 6685-6703, doi:10.5194/acp-9-6685-2009, 2009.

Ruppert, L. and Becker, K. H.: A product study of the OH radicalinitiated oxidation of isoprene: formation of C-5-unsaturated diols, Atmos. Environ., 34, 1529-1542, 2000.

Sillman, S.: The relation between ozone, $\mathrm{NO}_{\mathrm{x}}$ and hydrocarbons in urban and polluted rural environments, Atmos. Environ., 33, 1821-1845, 1999. 
Stevens, B. and Feingold, G.: Untangling aerosol effects on clouds and precipitation in a buffered system, Nature, 461, 607-613, 2009.

Surratt, J. D., Murphy, S. M., Kroll, J. H., Ng, N. L., Hildebrandt, L., Sorooshian, A., Szmigielski, R., Vermeylen, R., Maenhaut, W., Claeys, M., Flagan, R. C., and Seinfeld, J. H.: Chemical Composition of Secondary Organic Aerosol Formed from the Photooxidation of Isoprene, J. Phys. Chem. A, 110, 9665-9690, 2006.

Surratt, J. D., Lewandowski, M., Offenberg, J. H., Jaoui, M., Kleindienst, T. E., Edney, E. O., and Seinfeld, J. H.: Effect of Acidity on Secondary Organic Aerosol Formation from Isoprene, Environ. Sci. Technol., 41, 5363-5369, 2007.

Surratt, J. D., Chan, A. W. H., Eddingsaas, N. C., Chan, M., Loza, C. L., Kwan, A. J., Hersey, S. P., Flagan, R. C., Wennberg, P. O., and Seinfeld, J. H.: Reactive intermediates revealed in secondary organic aerosol formation from isoprene, Proc. Natl. Acad. Sci., 107, 6640-6645, doi:10.1073/pnas.0911114107, 2010.

van Donkelaar, A., Martin, R. V., Park, R. J., Heald, C. L., Fu, T. M., Liao, H., and Guenther, A.: Model evidence for a significant source of secondary organic aerosol from isoprene, Atmos. Environ., 41, 1267-1274, doi:10.1016/j.atmosenv.2006.09.051, 2007.

VanReken, T. M., Greenberg, J. P., Harley, P. C., Guenther, A. B., and Smith, J. N.: Direct measurement of particle formation and growth from the oxidation of biogenic emissions, Atmos. Chem. Phys., 6, 4403-4413, doi:10.5194/acp-6-4403-2006, 2006.

Verheggen, B. and Mozurkewich, M.: An inverse modeling procedure to determine particle growth and nucleation rates from measured aerosol size distributions, Atmos. Chem. Phys., 6, $2927-$ 2942, doi:10.5194/acp-6-2927-2006, 2006.

Virtanen, A., Joutsensaari, J., Koop, T., Kannosto, J., Yli-Pirila, P., Leskinen, J., Makela, J. M., Holopainen, J. K., Poschl, U., Kulmala, M., Worsnop, D. R., and Laaksonen, A.: An amorphous solid state of biogenic secondary organic aerosol particles, Nature, 467, 824-827, 2010.
Wyche, K. P., Blake, R. S., Ellis, A. M., Monks, P. S., Brauers, T., Koppmann, R., and Apel, E. C.: Technical Note: Performance of Chemical Ionization Reaction Time-of-Flight Mass Spectrometry (CIR-TOF-MS) for the measurement of atmospherically significant oxygenated volatile organic compounds, Atmos. Chem. Phys., 7, 609-620, doi:10.5194/acp-7-609-2007, 2007.

Wyche, K. P., Monks, P. S., Smallbone, K. S., Hamilton, J. F., Alfarra, M. A., Rickard, A. R., McFiggans, G. B., Jenkin, M. E., Bloss, W. J., Ryan, A. C., Hewitt, C. N., and MacKenzie, A. R.: Mapping gas phase organic reactivity and concomitant secondary organic aerosol formation: chemometric dimension reduction techniques for the deconvolution of complex atmospheric datasets, submitted to Atmos. Chem. Phys. Discuss., 2014.

Zhang, Q., Jimenez, J. L., Canagaratna, M. R., Allan, J. D., Coe, H., Ulbrich, I., Alfarra, M. R., Takami, A., Middlebrook, A. M., Sun, Y. L., Dzepina, K., Dunlea, E., Docherty, K., DeCarlo, P. F., Salcedo, D., Onasch, T., Jayne, J. T., Miyoshi, T., Shimono, A., Hatakeyama, S., Takegawa, N., Kondo, Y., Schneider, J., Drewnick, F., Borrmann, S., Weimer, S., Demerjian, K., Williams, P., Bower, K., Bahreini, R., Cottrell, L., Griffin, R. J., Rautiainen, J., Sun, J. Y., Zhang, Y. M., and Worsnop, D. R.: Ubiquity and dominance of oxygenated species in organic aerosols in anthropogenically-influenced Northern Hemisphere midlatitudes, Geophys. Res. Lett., 34, L13801, doi:10.1029/2007g1029979, 2007. 